DIVISION OF THE HUMANITIES AND SOCIAL SCIENCES

CALIFORNIA INSTITUTE OF TECHNOLOGY

PASADENA, CALIFORNIA 91125

CRIMINAL INVESTIGATION ENFORCEMENT ACTIVITIES AND

TAXPAYER NONCOMPLIANCE

Jeffrey A. Dubin

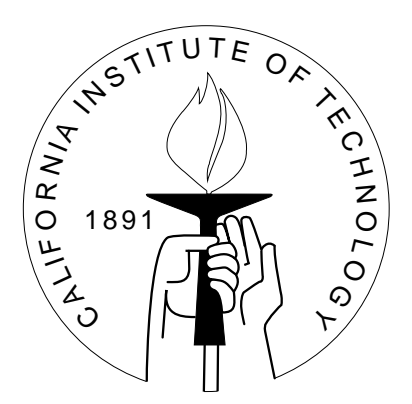

SOCIAL SCIENCE WORKING PAPER 1200

May 2004 


\title{
Criminal Investigation Enforcement Activities and Taxpayer Noncompliance
}

\author{
Jeffrey A. Dubin
}

\begin{abstract}
This paper tests empirically whether measurable activities of the IRS Criminal Investigation Division (CI) affect taxpayer compliance. The analysis is based on a state-level cross-section for the time period from 1988 through 2001. First, I find that CI activities have a measurable and significant effect on voluntary compliance. Second, I conclude that the mix of sentenced cases (tax and money laundering) is not a significant determinant of tax compliance. Third, media attention shows some weak evidence of increasing compliance, at least among money laundering cases. Fourth, I find that incarceration and probation (rather than fines) have the most influence on taxpayers. Simulations using the estimated models show that the direct effect of doubling the audit rate on assessed tax collections (reported amounts and additional taxes and penalties) is $\$ 18.7$ billion. Doubling CI tax and money laundering sentences is forecast to increase assessed collections by $\$ 16.7$ billion. I estimate the general deterrence or spillover effects from either audit or CI activities to be approximately 94 percent.
\end{abstract}

JEL classification numbers: $\mathrm{H} 26, \mathrm{H} 24, \mathrm{C} 33, \mathrm{C} 1$

Key words: tax evasion, personal income tax, panel data, econometrics 


\title{
Criminal Investigation Enforcement Activities and Taxpayer Noncompliance
}

\author{
Jeffrey A. Dubin ${ }^{1 *}$
}

\section{INTRODUCTION}

The annual tax gap (i.e., the difference between taxes owed and taxes paid) is estimated to be $\$ 200$ billion, or about 10 percent of what is collected each year from individuals and businesses. The Internal Revenue Service (IRS) estimates that three-quarters of this tax gap is attributable to individual taxpayers. At that rate, individuals currently represent $\$ 150$ billion of the tax gap, which is more than double the level estimated in $1985 .{ }^{2}$ While the tax gap has grown, the IRS' ability to audit and enforce the tax code has diminished. For instance, in 2002, the IRS had roughly 13,000 revenue and tax agents devoted to examination. This number is down from the 18,000 revenue and tax agents employed in 1995. Meanwhile, the Criminal Investigations Division of the IRS (CI) is considerably smaller. In 1970, CI had approximately 2,500 agents. By 1998, the number of CI agents had increased to approximately 3,000 agents. Due to the increases

\footnotetext{
${ }^{1^{*}}$ This research was sponsored in part by the IRS under the project: IRS Criminal Investigation ResearchEmpirical Analysis of the Impact of CI Activities on Taxpayer Compliance, TIRNO-00-D-0039. The author thanks Patrick Travers (Operations Research Analyst in CI Research), Peggy Opeka (Program Analyst in CI Research), Debbie King (Director of CI Research), Alan Plumley (Economist and Technical Advisor in IRS Office of Research), Mark Matthews (IRS Deputy Commissioner for Services and Enforcement), Colleen McGuire (Senior Associate, ICF Consulting), as well as seminar participants at the IRS Research Conference. James Lin (Pacific Economics Group) provided excellent research assistance.

${ }^{2}$ The tax gap attributable to individual taxpayers has grown from $\$ 70$ billion in 1985 to $\$ 95$ billion in 1992 (the date of the last Taxpayer Compliance Measurement Program [TCMP] measurement).
} 
in the tax gap, it is important to reassess the role played by examination in taxpayers' voluntary compliance and to ascertain what effect CI investigations play in general deterrence.

The empirical approach used in this paper follows Dubin, Graetz and Wilde (1990) (DGW). The DGW method can determine both specific and general deterrence effects of CI activities, as well as the effects of audit rates on taxpayer compliance. Although the general deterrence effects provided by audits have been widely acknowledged, the IRS has never reported the "spillover" benefits provided by audits. Spillover benefits are the increase in collections from taxpayers, whether or not they are audited, who report more taxes in response to an increased likelihood of an audit. DGW's principal innovation was to directly estimate taxes due, rather than first attempting to construct a noncompliance measure and then extrapolating from noncompliance to revenue.

The current study's purpose is to answer several basic questions. First, does CI have a measurable effect on voluntary compliance, which includes both civil and criminal tax laws? Second, if CI does have a measurable effect on voluntary compliance, what mix of CI investigations has the greatest influence on voluntary compliance? (CI investigates two broad categories of cases: tax violations and money laundering violations.) A subsidiary inquiry is whether either or both types of cases have an effect on voluntary compliance with the tax laws. Third, does media attention and publicity on CI investigations increase the compliance effect? Fourth, do convictions that result in prison sentences affect compliance differently from cases that result in probation?

In this paper, I empirically test whether the CI's measurable activities affect taxpayer compliance. ${ }^{3}$ I replicate and extend the original DGW analysis to include factors that measure CI activity. The time period covered by the new model is 1988-2001. I reach several conclusions. First, I find that CI activities have a measurable effect on voluntary compliance. I found

\footnotetext{
${ }^{3}$ The Webster Report (Review of the IRS' Criminal Investigation Division (William Webster), April 1999, observed that a previous lack of empirical evidence "makes it impossible to prove that the cases CI has investigated previously and is currently investigating either do or do not foster compliance." In this study, I provide the empirical evidence that Judge Webster sought.
} 
statistically significant results from my measure of CI sentenced cases on general tax deterrence. Second, I conclude that the mix of sentenced cases (tax and money laundering) is not a significant determinant of tax compliance. Third, media attention shows some weak evidence of increasing compliance, at least among money laundering cases. However, it is logical to think that media attention plays an important role in disseminating information to the public. The significant magnitude of general deterrence results implies that media plays a large role in CI cases. Finally, I find that incarceration and probation (rather than fines) have the most influence on taxpayers.

I also performed simulations to determine the direct revenue (spillover) effect of audits and $\mathrm{CI}$ activities. I find that the direct effect of doubling the audit rate on assessed tax collections (reported amounts and additional taxes and penalties) is $\$ 18.7$ billion. Doubling CI tax and money laundering sentences is forecast to increase assessed collections by $\$ 16.7$ billion. I estimate the spillover effects from both audit and CI activities to be approximately $94 \%$. Doubling the audit rate or doubling money laundering sentences produced similar increases in total collections.

The remainder of the paper is organized as follows. In Section 2, I review the empirical tax evasion literature. In Section 3, I discuss the process of criminal investigations and potential influences on taxpayer compliance. In Section 4, I discuss the methodology, data, and results of the econometric models. Section 5 presents the results of several simulations, and Section 6 offers some conclusions.

\section{LITERATURE REVIEW}

Andreoni, Erard, and Feinstein (1998) and Slemrod and Yitzhaki (2002) provide summaries of the tax compliance literature. As discussed by these authors, the IRS has made available to researchers few data sources that can be used to study tax compliance. With respect to non-experimental and non-survey data limited to the United States, there continues to be limited data. As discussed in the authors' review, there are essentially two data sources. The first data source is the Taxpayer Compliance Measurement Program (TCMP) data. These data have 
been analyzed by Dubin and Wilde (1988), Witte and Woodbury (1985), and Beron, Tauchen, and Witte (1993) for tax year 1969. These were important empirical papers on audit effects and compliance because they demonstrated endogeneity of audit rates and positive compliance effects from audits on certain audit classes. Subsequently, Dubin, Graetz, Udell, and Wilde (1992) used 1979 TCMP data to study tax return preparation decisions by taxpayers. Kamdar (1995) also utilized TCMP data in studying information return. Recently, Mete (2001) combined TCMP surveys conducted by the IRS for several tax years in studying the interaction among taxpayers, the IRS, and political ideology.

The second data source is based on time-series cross-sectional information available by state and year. Measures of audit activity, taxes assessed, and taxes collected are taken from the Annual Reports of the Commissioner of the IRS. For instance, DGW (1990) used IRS audit data and taxpayer information measured at the state level over a 10-year period in analyzing taxpayer noncompliance. Ali, Cecil, and Knoblett (2001) also relied on data taken from the Annual Reports. Their analysis was based on 1980 through 1995 annual data (i.e., 16 observations). Their model specification included two equations: reported income (as a function of actual income, audit rates, and other factors) and an audit rate equation. Ali et. al. used filing status categories rather than geography in a pooled estimation procedure. However, their instrument for audit rates was insignificant, leading to imprecise estimates of audit effects. Giles and Caragata (2001) present an aggregate analysis similar to DGW (1990). Their study analyzed the ratio of the hidden economy to Gross Domestic Product (GDP) and the ratio of tax revenues to GDP. ${ }^{4}$

Plumley (1996) extended the analysis in Dubin, Graetz, Wilde (1990). His time-series cross-section analysis covered the period 1982-1991, whereas the DGW study used data from 1977-1986. Importantly, Plumley was the first to show that CI activities (measured as criminal convictions obtained per million people) were significant and positively related to compliance. ${ }^{5}$

\footnotetext{
${ }^{4}$ The similarity to DGW is due to using proxy evasion measures for the economy rather than direct evasion measures. Another similarity is using a time-series data source as opposed to a purely cross-sectional data source, such as the 1969 TCMP. However, DGW (1990) combined both cross-sectional and time-series information in their empirical analysis.

${ }^{5}$ Plumley modified some of the DGW reporting and compliance equations by using: (i) income and offsets rather than tax collected; and (ii) tax return filings relative to expected filings rather than to population. Plumley
} 


\section{BACKGROUND}

One of CI's functions is to investigate alleged violations of the tax and money laundering statutes. CI has focused its activities for some time on narrowing the tax gap. Tax gap investigations include both tax and money laundering cases that involve tax issues. Tax gap investigations normally do not include illegal activity associated with narcotics investigations. Tax-related investigations encompass all Title 26 violations (tax evasion, failure to file, filing of false returns, fraudulent returns, or aiding or providing assistance to fraudulent returns) as well as tax violations that fall under Title 18 USC $\$ 286,287,371$ (conspiracy to defraud the government or commit offense or false claims). CI also has jurisdiction over Title 31 cases (currency reporting violations). CI tax investigations are so-called legal source tax crimes because they encompass all cases involving tax violations where income is derived from legal activity, including questionable refund schemes, return preparer cases, excise tax cases, employment tax cases, and frivolous filers and nonfilers. CI also investigates illegal source financial crimes and narcotics-related financial crimes.

The CI is literally the IRS' criminal investigation arm. It is the only federal agency with the power to investigate potential criminal violations of the U.S. Tax Code. CI's tax cases sometimes result from referrals by the IRS' civil arm. During an audit or tax investigation, a case might be referred to the CI for criminal investigation. ${ }^{6}$ However, audits are not the sole source for tax-related cases. CI may investigate a tax case initiated by a special agent in the field, a referral from another agency (FBI, Customs, or the US Attorney or DOJ), informants, as part of the Grand Jury process, or as a result of refund fraud-related activity.

While the IRS can investigate and audit tax returns and recommend civil penalties, CI has the exclusive responsibility and authority to investigate tax fraud and to recommend prosecution for willful and egregious tax code violations. CI's role as a tax crimes agency expanded in 1970

introduced refinements to the DGW audit rate measure (based on start rates versus closure rates) and considered new factors for taxpayer burden and CI enforcement activity.

${ }^{6}$ DGW (1990) noted that fewer and fewer cases were being referred to CI from audits over the period from 1979 to 1988 . The Webster report also noticed and discussed this same trend. 
under the Bank Secrecy Act (BSA) and has been further expanded over the last 30 years to include narcotics investigations and money laundering violations. Money laundering cases often result from the record keeping requirements established in the BSA. ${ }^{7}$

Money laundering activity and tax activity can be closely related. Money laundering activity (i.e., activity involving illegal income sources) is often a precursor to tax evasion. As such, it is sometimes difficult to determine whether a case is primarily tax related or not. CI has been able to classify its cases in terms of whether they are primarily tax related or money laundering related. CI has further classified cases according to whether they are both tax and money laundering cases, tax cases only, money laundering cases only, or neither. For this study, I treated any case with a tax-related component as a tax case and any case with a money laundering component as a money laundering case.

CI summarizes its activities in different ways. First, CI reports its cases by the Title and Section of law for which there is a violation or an alleged violation. For fiscal year 1999, for example, CI reports cases recommended for prosecution as follows: 1,068 for Title 26 violations; 1,988 for Title 18 violations; and 64 for Title 31 violations. Of these 3,120 cases, CI further classifies 1,959 cases as fraud related and 1,161 cases as narcotics related. Tax cases, in this study, include all primary and secondary recommended violations of tax-related offenses (Title 26, 18-287, 18-286, 18-371K). Money laundering cases, in this study, include all primary and secondary recommended violations of money laundering-related offenses (Title 18-1956, 18371T, 18-371M, 18-1960 or Title 31).

A criminal investigation case proceeds in several steps. Generally, cases subject to investigation are either recommended for prosecution or are dropped. If a case is recommended for prosecution, then the Department of Justice (DOJ) or U.S. Attorney may proceed with the case, and the U.S. Attorney either issues an indictment or declines to prosecute. Indicted

\footnotetext{
${ }^{7}$ These requirements stipulate that banks must (1) report certain large currency transactions; (2) disclose foreign bank accounts; and (3) report currency movements across the border. These regulations trigger reporting currency transactions involving dollar amounts over $\$ 10,000$. In addition, the Money Laundering Control Act established criminal offenses for engaging in unlawful monetary transactions. More recently, in 1996, financial institutions were required to report suspicious financial activity that could indicate loan fraud or money laundering.
} 
individuals may be acquitted, have their case dismissed, or be convicted. If a conviction is obtained, then the individual is sentenced. In this study, I analyzed CI activities from the perspective of cases recommended for prosecution and from the perspective of successfully prosecuted cases where the defendant was sentenced. Cases recommended for prosecution represent the outcomes of the CI procedures and protocols. Such cases may or may not be processed by the DOJ depending on the nature of the case or resource constraints at the DOJ. In most cases where there is an indictment, defendants will be found guilty and will be sentenced. At this point in the process, the sentence is given and the media attention paid to the case is measured. The impact on compliance can be experienced whenever publicity is received. This may include the coverage of an issued search warrant, an indictment, a plea, or a conviction. Media coverage acts as a form of indirect contact with the general public and provides the greatest amount of exposure for CI activities.

\section{DATA AND MODEL SPECIFICATION}

As discussed above, this study's purpose is to update and extend DGW (1990) to analyze the role of CI activities on taxpayer noncompliance. The DGW empirical analysis was based on two models that are both estimated using a state-level time-series cross-section. One model specified reported taxes per return filed as a function of audit rates and a variety of socioeconomic factors. The other model specified returns filed per capita as a function of the same variables.

\subsection{DATA}

The DGW analysis was based on data reported in the Annual Report of the Commissioner of Internal Revenue for the years 1977-86. These reports include district-level data on IRS collections, number of returns filed, amount and number of refunds, number of examinations, total additional tax and penalties recommended after examination, and budgets. The data employed, in this study, is a compilation of annual tax enforcement, criminal investigation, socioeconomic, and political statistics for each U.S. state from 1977 to 2001. The tax collections and examination variables rely on data reported in the Annual Report of the Commissioner of Internal Revenue, IRS Data Book, and IRS Statistics of Income Bulletin. 


\section{A. DEPENDENT VARIABLES}

The dependent variables are (i) ALR (Assessed Liability Per Return): reported individual income tax plus additional tax and penalty recommended after examination divided by the number of individual income tax returns filed, in 1972 dollars; (ii) RTR (Reported Taxes Per Return): reported individual income tax divided by the number of individual tax returns filed, in 1972 dollars; and (iii) RCAP (Returns Per Capita): reported total individual income tax returns filed divided by total population.

\section{B. IRS ENFORCEMENT FACTORS}

The effect of audit examination on compliance is as important in the current analysis as it was for the original DGW study. The audit rate is defined as AUDIT (Individual Audit Rate): reported total individual income tax returns examined divided by total individual income tax returns filed and is treated endogenously. ${ }^{8}$ The dramatic decline in the individual audit rate (IAR) between 1977 and 1987 was followed by an equally staggering decline during the subsequent 15 years. Indeed, audit rates fell from 1.98 percent in 1977 to 0.59 percent by 1991 . The decline continued through the end of the analysis period, until the individual audit rate was only 0.15 percent in 2001 . The IRS indicates that this decline in audit rates has been partially offset by automated programs such as the CP2000 program and other correspondence audits. I examine this proposition below. Meanwhile, individual returns filed per capita (RCAP) grew steadily over the 25 -year period by 18.44 percent, or 0.74 percent per annum.

As part of this study, the IRS provided several new factors to examine tax enforcement. These factors refine the individual audit rate used in DGW but are limited to a subset of the analysis period (from 1993 forward). The first factor measures examinations of individual tax

${ }^{8}$ Statistics on examination coverage variables such as numbers of returns examined, additional taxes and penalties recommended after examination, and costs incurred by the IRS were broken down by district office and service center in the IRS Data Book and Annual Report. In states where there were multiple districts, I performed an aggregation to derive state-level figures for those factors. The IRS Reform Act reorganized the entire district system and required many district offices to be responsible for the tax returns filed by multiple states. As a result, most of the district-level statistics from 1997 to 2001 included services provided to multiple states. Since only state-level data is used in the analysis, I took the 1996 allocation of examinations, additional taxes, and cost incurred for each state among all states in the newly defined districts and extrapolated the annual figures for 1997-2001 based on the 1996 percentages. For states with multiple districts, the district-level data is aggregated to the state level. 
returns conducted by revenue agents (AUDR1). Revenue agents are required to have extensive accounting knowledge. Revenue agents typically audit more complex issues that involve higher income levels or greater deductions. Revenue agents conduct their audits in person rather than through the mail. As with the audit rate defined in the DGW study, I express the revenue agent audit rate as a fraction of individual returns examined. Revenue agent audits have declined significantly between 1994 and the present. The rate of these audits fell from 0.313 percent to 0.065 percent during the period.

The second examination factor represents the tax agents' audit activity. Tax auditors or tax agents generally have less tax knowledge than revenue agents. They typically audit individual non-business returns and Schedule $\mathrm{C}$ returns (sole proprietorships). Relative to revenue agent audits, tax audits are less complex and involve lower income and expense levels. Expressed as a fraction of individual returns filed, tax audits (AUDR2) also show a dramatic decline over the last decade. The rate of these audits fell from roughly 0.428 percent to 0.086 percent by the end of the period. ${ }^{9}$

Finally, the IRS provided a measure of correspondence audits. These audits are done through the mail, as the name implies, and represent a modern extension of the CP2000 program [see DGW (1990)]. I attributed service center audits to the state in which the taxpayer resided. Normalizing by individual returns filed yields the third audit factor (AUDR5). Correspondence audits have increased from 0.261 percent in 1993 to 0.962 percent in 1996. In recent years, however, the rate of correspondence audits has declined; the 2001 measurement shows an average rate of just 0.395 percent.

9 Statistics on the number of examinations and additional taxes and penalties were not published in the data book after 1999 and 1997, respectively. In order to have the two variables span the entire period, I substituted the data obtained directly from the IRS for the published data in the post-1993 portion of the dataset. The sum of audits performed by both revenue agents and tax auditors tied out closely to the number of audits reported in the Data Book. Therefore, I used the factor (AUDR12) to extend the DGW in later years. I used the same approach for additional taxes and penalties. In the years where the new data and published data overlap, the correlation between the original and updated versions of the audit variable is 0.92 . Similarly, the correlation between the two versions of the additional tax variable is 0.97 . The resulting variable is denoted IAR2 and extends the DGW factor IAR for recent years where the IRS data books no longer report audit rates by state. 


\section{INSTRUMENTAL VARIABLES}

With respect to instrumental variables, I extended the budget per return variable (BPR): reported total IRS budget divided by total returns filed, in 1972 dollars) used in the DGW study and added some new instruments. First, the IRS budget per individual return filed was estimated and published by the IRS through 1999. The budget (in real 1972 dollars) reached its peak of $\$ 5.29$ per return in 1988. The growth was likely a consequence of the Tax Reform Act of 1986 (TRA).$^{10}$ However, the budget per return subsequently underwent a significant decline between 1993 and 1999 , dropping from $\$ 5.18$ to $\$ 3.69$, ultimately falling to levels lower than those in any of the previous years in the analysis. ${ }^{11}$

Next, the IRS provided a measure of the total available resources devoted to examinations [DIR_EXAM (Direct Examination): Percentage of all examiners' time allocated to direct examination of the returns. $]^{12}$ This percentage further refines the budget variable described above; it should be highly correlated with audit activity but nevertheless exogenously set by the IRS in any fiscal period as it corresponds to the planned examination activity. ${ }^{13}$ Beginning in 1980 with a state average of 64.4 percent, the direct examination percentage fell to 41.1 percent by 1988 . While the percentage of time devoted to examinations rose somewhat through 1997 (to 54.1 percent), the pattern from 1997 to 2001 had been to reduce direct examination time (measured at 36.9 percent in 2001).

In some models, I needed additional instruments, as I discuss further below. Following Mete (2002), I assembled several political factors that could be used as potential instruments. Based on correlations with the audit rate, I ultimately focused on four potential instruments: (1) the political party of the state governor (GOVR); (2) a measure for state government liberalism (GOVIDO); (3) the ratio of Democrats to Republicans in the House (HRATIO); and (4) the ratio

\footnotetext{
${ }^{10}$ The TRA was a major shift in United States tax policy. Tax rates were cut, the tax base was broadened, IRA rules were changed, and the tax laws were generally simplified.

${ }^{11}$ Given the importance of this factor as an instrument for IRS audit levels, I extended this figure for the 2000 and 2001 period at 1999 levels. There is little consequence from this approximation when budget per returns filed is used as an instrumental variable.

${ }^{12} \mathrm{DGW}$ used a measure of information returns filed as an instrument in some of their models, but this factor was not available at the state level for the time period covered in this study. audit activity.

${ }^{13}$ As discussed by Plumley (1999), the direct examination measure is a reasonably exogenous measure of
} 
of Democrats to Republicans in the Senate (SRATIO). ${ }^{14}$ Based on the empirical results, I ultimately selected the instrument based on government liberalism and used it in conjunction with IRS budget per return filed and the direct examination percentage. I then used these instruments in a subset of models that simultaneously considered three examination factors.

\section{SOCIOECONOMIC FACTORS}

I followed DGW and used several socioeconomic explanatory variables, all reported on a calendar year basis: STAXR (Average State Income Tax Rate): total state individual income tax paid as a percentage of total state personal income; PERED: percentage of the adult population with at least a high school education; PER65: percentage of the adult population over age 65; UI: the unemployment rate; PICAP: income per capita, in 1972 dollars; PMAN: percentage of the workforce employed in manufacturing; PSERV: percentage of the workforce employed in the service industry; HOUSES: households per capita; FRMFAM: farms per household; and PWELFAM: the percentage of all households on welfare.

Most of the explanatory factors appeared to continue the trends first discussed in DGW. First, the percentage of families on welfare (PWELFAM) declined slightly during the 1970's and 1980 's, falling from 4.70 to 4.08 percent, before rising to its peak of 5.17 percent in 1994. From 1995 through 2001, the percentage of families on welfare declined to 2.03 percent. This decline may have been due to welfare reform enacted in the Personal Responsibility and Work Opportunity Reconciliation Act of 1996 (Personal Responsibility Act). Welfare cases necessarily fell when fewer individuals qualified for welfare under the PRA.

Next, the number of farms per household (FRMFAM) continued to show a decline during the analysis period, reflecting fewer farms in the United States and a larger number of households. The decline was from 3.30 farms per hundred families to just over 2.06 farms per

\footnotetext{
${ }^{14}$ Mete (2002) provides the rationale behind these factors and discusses how they are expected to correlate with the audit rate. Mete argues that Republicans prefer lower levels of enforcement for all forms of regulation than do Democrats. Additionally, Mete argues that Republicans provide less support for increasing government spending and enforcement activities than Democrats. Therefore, the undesirable effects of tax enforcement on citizens may be worse for Republican politicians. Thus, a higher proportion of Democrats in Congress or a more liberal ideology score should lead to generally higher audit rates.
} 
hundred families. Unemployment rates (UI) varied notably during the late 1970's and 1980's. Reaching a peak in the early 1980's (at 9.23 percent), unemployment has generally declined with the exception of the recession in the early 1990's and the increase in unemployment that has occurred in recent years.

Personal income in real terms (PICAP) rose steadily from 1977 through 2001. Average real income per capita rose from $\$ 5,066$ to $\$ 8,017$. State tax rates (STAXR) rose on average from 4.06 percent in 1977 to 4.52 percent in 1984. From the mid-1980's forward, the state tax rate grew to 4.74 percent and remained fairly steady at this level in the late 1990's.

The percentage of the population over age 65 (PER65) showed a relatively modest growth during the period. The percentage of employed individuals in manufacturing (PMAN) declined from just over 21.45 percent in 1977 to roughly 12.94 percent by 2001 . The percentage of employed individuals in service industries (PSERV) increased from 16.61 percent in 1977 to nearly 29.49 percent in 2001. This pattern continues the trends described in the original DGW study. However, as described more fully below, the importance of manufacturing and service industry employees may have changed as compliance and collections associated with these sectors have shifted since the original 1977-1986 study of DGW.

\section{E. CI ENFORCEMENT FACTORS}

The CI provided detailed information about sentenced cases and cases recommended for prosecution, including media coverage and sentence type (typically probation or prison). The sentence counts were first broken down by the crime that was committed and then further distinguished by the sentence's punishment (prison or probation) and by whether news of the case was released through any form of media (radio, television, print). My analysis begins by decomposing all $\mathrm{CI}$ cases that were sentenced. Sentenced cases can arise as a result of a pure tax investigation, a pure money laundering investigation, a combination of both tax and money laundering investigations, or something not related to either tax or money laundering. The preponderance of CI cases had either tax or money laundering aspects. In addition, sentenced cases may or may not have received media coverage. Finally, sentenced cases may have received recommendations for prison, probation, or some other fine or penalty. There are many ways in 
which to classify individual CI cases. Finding the empirical classifications that have significance with respect to tax compliance is one of the goals in this study.

Money laundering cases, in this study, are not considered tax gap cases, except for a few cases that were both tax and money laundering related. I allocated these cases to both the tax and money laundering category. It is natural to consider how such cases can affect taxpayer compliance. The most plausible mechanism is through publicity. It is possible that a CI-related activity that receives media attention may influence some taxpayers to be more tax compliant. It is also possible that media coverage of money laundering cases and the sentences received by the individuals under indictment convey the mission of the CI division and emphasize its role in tax matters. To the extent that media variables are measurable for a reasonable time period, analysis of media attention provides a direct test of the CI message mechanism. Ultimately, it is an empirical question and one that I investigate in this paper.

Total CI cases recommended for prosecution (TOTP) ranged from 2,937 cases per annum in 1988 to 4,126 cases in 1993. TOTP fell to 2,271 cases in 2001. Annual counts of CI tax cases recommended for prosecution (TP) reached 2,255 in 1993 but then fell dramatically to 991 cases by 2001. Money laundering cases recommended for prosecution (MP) grew rapidly, from 385 cases in 1988 to 2,042 cases in 1992, nearly equaling the number of tax prosecutions for the same year $(2,047)$. Interestingly, annual counts of money laundering prosecutions became greater than tax prosecutions beginning in 1997, and they have remained that way every year since.

Total CI sentenced cases (TOT) ranged between 2,133 and 3,157 during the period from 1988 through 2001. There is some evidence of a recent decline in the total cases performed by CI. Tax cases conducted by CI (T) have declined fairly steadily from 1988 to 2001 and declined from 1,876 cases per annum in 1998 to 899 cases in 2001. Conversely, money laundering cases (M) have risen from 132 cases per year in 1998 to a high of 1,170 cases per annum in 1994. There are approximately 900 such cases conducted per year at present.

On a percentage basis, these patterns are quite dramatic. The number of CI tax cases as a percentage of total CI cases (T_TOT) fell from 76.9 percent in 1988 to 42.2 percent in 2001. 
Meanwhile, money laundering cases rose from just 5.4 percent of all CI cases (M_TOT) to 41.2 percent by 2001. ${ }^{15}$

I next turn to tax-only case disposition. Similar to tax and money laundering cases, an individual who is sentenced may receive prison time, probation, both prison and probation, or neither (typically a fine of some kind). Unlike the situation with tax and money laundering sentences, where few cases were sentenced for both tax and money laundering violations, most tax cases have both prison and probation components. For instance, in the 50 states and for the years 1998-2001, there were 21,604 tax sentences. Only 507 cases received neither prison nor probation, while 11,719 cases received both. There were 11,660 tax sentences resulting in prison sentences, but only 2,941 of these cases were prison-only sentences. ${ }^{16}$

With respect to the way cases are disposed, tax cases that received prison sentences (TPRI) averaged 1,037 per annum from 1989 through 1998. After 1998, there was a decline to 726 cases per annum in 2001. The number of tax cases that received probation (TPRO) fluctuated around 1,300 cases per annum from 1988 to 1998. In 2001, the amount declined to 811 cases per annum. Money laundering cases receiving prison sentences (MPRI) increased dramatically from 80 cases per annum in 1988 to 1,041 cases per annum in 1994 . There was an average of 863 cases per annum in the subsequent years from 1995 to 2001, with 785 cases per annum in 2001. Money laundering cases receiving probation (MPRO) followed a very similar pattern, rising from 68 cases per annum in 1988 to 727 cases per annum by 2001 .

\footnotetext{
${ }^{15}$ As the percentages reveal, a small number of cases conducted by CI are classified neither as money laundering nor tax cases. Similarly, there are a few cases that have aspects of both money laundering and tax. I have included such cases as both money laundering and tax cases. The amount of double counting is, however, insignificant.

${ }^{16}$ The overlap in money laundering sentenced cases was similar. Of 11,865 sentenced money laundering cases, 164 received neither prison nor probation, while 7,789 received both sentence types.
} 
Media attention for tax cases rose between 1992 and 1997. It then fell starting in 1998, continuing to decline through $2001^{17}$. Media attention for money laundering cases followed a similar pattern, peaking in 1997. Cases receiving media attention (MD) rose from 1,102 in 1992 to 2,539 per annum in 1997. However, more recently, the coverage of CI cases in the media has declined to 1992 levels (when such figures were first tracked by the CI division).

Tax cases receiving media attention as a percentage of all media cases (TMD_MD) and money laundering cases receiving media attention as a percentage of all media cases (MMD_MD) show some modest variation, with money laundering cases receiving a growing percentage of coverage by the media. These two categories do not exclusively exhaust media attention, but the residual coverage is very small in percentage terms.

With respect to sentencing, the patterns are more dramatic. The percentage of all money laundering cases where the defendant received a prison sentence (MPRI_M) has grown from 60.6 percent in 1988 to 87.4 percent in 1992. During the last decade, this rate has grown further to 91.5 percent of money laundering cases in $1997 .{ }^{18}$

Similarly, the percentage of CI money laundering cases receiving probation (MPRO_M) grew from 51.5 percent in 1988 to 85.7 percent in 2000. The CI division has also managed to improve its sentencing rate for prison and probation among its tax cases. The percentage of CI tax cases receiving prison sentences (TPRI_T) rose from 56.8 percent in 1988 to 80.8 percent in 2001. Similarly, the percentage of tax cases receiving probation among all CI tax cases (TPRO_T) rose from 74.1 percent in 1988 to 90.2 percent in 2001. This trend is also reflected in the rate of prison sentences received as compared with individual returns filed. Dramatic increases in prison sentences are evident when comparing the number of cases receiving prison

\footnotetext{
${ }^{17}$ The media data provide the number of cases that received media attention and the type of media coverage given (i.e. newspaper, television, or radio). However, the data do not reveal the amount of media attention a case received.

${ }^{18}$ This growth cannot be attributed to mandatory sentencing guidelines already in place during this period and must reflect an increase in efficiency of the $\mathrm{CI}$ in choosing cases.
} 
sentences to the number of returns examined. However, the prison sentence rate is still more than 100 times smaller than the audit examination rate for individuals. ${ }^{19}$

\subsection{MODEL SPECIFICATION}

DGW selected explanatory variables for the "reporting effect" equation based on two considerations: the size of the tax base and the taxpayers' compliance behavior. ${ }^{20}$ The variables primarily related to the tax base are PER65, HOUSES, and WELFARE. The variables related to both the tax base and taxpayers' compliance behavior are UR, INCOME, and STAXR. The variables primarily related to the taxpayers' compliance behavior are PERED, PMAN, PSERV, FARMS, and AUDIT. ${ }^{21}$

Additional compliance factors include variables created as part of this study to measure the nature and extent of CI activities. I treat CI activities as exogenous both on theoretical and empirical grounds. First, CI activity is largely a result of cases discovered and selected for examination that arise independently of tax gap or noncompliance issues. Second, Hausman specification tests for endogeneity of the CI enforcement factors did not reveal endogenous behavior.

\section{ECONOMETRIC ANALYSIS}

In principle, the additions to the original DGW study to accommodate criminal investigation factors are straightforward. In fact, the task is far more complex than simply creating and matching various factors from CI and then adding these factors to the basic model. For example, individuals face a complex decision process with respect to criminal activity. An individual may be deterred from tax evasion, money laundering, or other criminal acts based on

\footnotetext{
${ }^{19}$ Conviction rates have also increased in comparison to the 1978 through 1988 period. Here, I define the conviction rate as the total number of CI cases that are sentenced as compared to returns examined. The figures demonstrate the rapid increase in conviction rates for the CI division. However, as noted by DGW, the sentences at issue may not be a result of cases that are selected for tax examination.

${ }^{20}$ The effects of these variables on reported taxes per return are based on conventional theoretical considerations. For a full discussion, see DGW(1990).

${ }^{21} \mathrm{I}$ expected increases in the federal audit rate (AUDIT) to increase taxpayer compliance (and thus reported taxes per return), since audit rates presumably respond to compliance levels. Therefore, I cannot treat the federal audit rate as an exogenous factor.
} 
the likelihood of being caught. This deterrence possibility has been the empirical paradigm of modern criminal analysis. In this approach, a potential criminal may be deterred from committing a crime due to a sufficiently high probability of being caught and receiving a sufficiently severe penalty. Of course, not all individuals are rational actors with respect to the crimes they commit. However, a rational calculus applied to crime and punishment is a benchmark test and provides policy makers with justification for increasing enforcement levels or changing the enforcement mix. Ultimately, the manner in which individuals respond is an empirical matter. Thus, in this approach, I assume that individuals consider the likelihood that they will be detected and punished.

With respect to civil audit examination, a measure such as the audit rate may be significant to a potential tax evader because it measures the probability that the taxpayer will be subjected to an audit. In the current setting, the natural analogue to the audit rate is the rate at which CI investigations are commenced or the rate at which prosecutions are recommended. Prosecution rates are, in fact, quite small for individual taxpayers. As I noted above, these prosecution rates may be orders of magnitude smaller than the individual audit rate. A compounding factor is that not all cases recommended for prosecution lead to indictments, and not all indictments lead to sentencing. In contrast, the audit rate leads to an audit whether or not a change in the taxpayer's liability is recommended. By focusing on cases sentenced, an exposure measure is produced that is closer to the audit rate but results in a factor that, in relative magnitude to the population at large, is quite small. Additionally, as a matter of general deterrence, it is believed that individuals respond to the probability of detection. The question remains as to how they learn the rates at which they are likely to be caught. Attention by the media would seem to be the most likely forum by which taxpayers become aware of the likelihood that their crimes will be detected. Therefore, those cases that are successfully prosecuted and sentenced and receive some media attention would appear to be most relevant. Finally, taxpayers may be concerned only with the sentences that result in incarceration or probation as compared to monetary fines. Thus, the percentage of sentenced cases that result in non-monetary fines may be relevant. 
Taxpayers may respond to the probability of an audit in a rational calculus that affects their decision to file a tax return or the degree to which they file an honest and correct return. This theory is known as deterrence theory in the literature. It has also been persuasively argued that taxpayers may react to the actions of other taxpayers, especially as those actions concern notions of fairness and support for their decisions to voluntarily comply with the law. This theory of taxpayer behavior is known as assurance theory (see, e.g., Roth et. al. 1989, Scholz 1998, Scholz and Lubell 1998a,b). Models of conformity and social dynamics (see e.g. Durlauf and Young, 2001) postulate that the utility of a given decision may in part be determined by the expected actions of others. Models of social dynamics bridge the deterrence and assurance theories of taxpayer compliance. Importantly, Manski $(1993,1995)$ has shown that for linear models with aggregate data there is an inherent identification problem that may not allow the theoretical issue to be resolved empirically. ${ }^{22}$

As an empirical matter, many non-exclusive approaches could have significance. Among the choices are: (1) separating tax and money laundering rates; (2) separating media cases from non-media cases; and (3) the sentencing mix. With three types of CI cases (tax, money laundering, and other), media (Yes versus No, or type of coverage), and at least three sentencing outcomes, variables that can be used to measure CI activities quickly expand relative to the available years and geographic locations available for analysis. My approach simplified the relevant set of $\mathrm{CI}$ factors as much as possible, while considering specifications and models that would allow a full picture to emerge.

\section{V.1 EMPIRICAL INVESTIGATION}

As discussed, the original DGW model used data for the years 1977-1986. Adding data for later years more than doubled the observations. However, the overall explanatory power of the model fell in this full data period. This change, coupled with changes in the pattern of coefficients for some factors, suggests that the period after 1987 (and therefore after the time

\footnotetext{
${ }^{22}$ Our finding that CI enforcement levels are significant determinants of taxpayer compliance would reinforce the assurance theory aspects of behavior rather than the deterrence theory. Conversely, the empirical support for significant audit rates found in this study and others suggest that deterrence theory is equally valid for types of taxpayer behavior.
} 
period considered in the original DGW study) was different from the earlier period in significant ways.

Focusing on the period after 1987, the re-estimated models showed some sign changes in socioeconomic factors, including a shift in the roles played by the percentage of employed populations in manufacturing and service industries. Since these effects were previously understood in terms of the possibility for individual noncompliance and opportunities to evade, it is more likely that a change in IRS policy to focus attention on service industry geographies or a change in the relative economic conditions of these two sectors explains the change in predicted compliance.

Several empirical experiments showed that CI factors have statistical significance when considered as counts. However, little significance remains when these counts are expressed as rates. While a theoretical justification may be made for using rates as estimates of probabilities, and while probabilities are motivated by the theoretical criminology and economics literature, the empirical finding is that these rates are just too small to reveal any correlation with compliance. However, the finding that absolute counts matter is interesting and suggests that general deterrence may result from the overall level of CI activity rather than the rate at which these investigations take place. This interpretation affirms the assurance theory of CI activity.

In Table 1, I present the estimated econometric models in a logical progression from the DGW specifications to the final models used in this paper. The model of DGW (1988) is a steady state equilibrium relationship. It is assumed that all effects are in long-run equilibrium. However, as audit rates change, taxpayers are assumed to change behavior and modify their reported taxes due. At first blush, it is reasonable to assume that reported taxes in a given year react to audit rates that prevail in that year. However, the typical IRS audit cycle may not initiate an audit for several years following the filling of a tax return. Taxpayers, in this situation, must react to their expectation of future audit rate levels. Alternatively, the additional taxes and penalties reported in a given tax year may to some degree depend on the audits of tax returns from previous years. Hence, additional taxes and penalties may be some function of past audit rate levels. Finally, taxpayers may change their reported taxes due in a continuous adjustment to 
a new target level. There may be the perception, by some taxpayers, that a rapid or discontinuous (abrupt) change in behavior may be a signal to the IRS of an existing or current tax problem. Such taxpayers may adjust their reported taxes based on a mixture of taxes reported in the previous year and the optimal level of taxes due based on existing or current conditions.

I investigated the dynamic panel specification using methods due to Anderson and Hsiao (1981). See also Anderson and Hsiao (1982), Arellano (1989), and Arellano and Bond (1991). The empirical results indicate that a short-term dynamic is most likely at work, with the majority of adjustment occurring within two to three years after a change in tax policy. Interestingly, this period of time for adjustment and audit expectation formation naturally corresponds to the audit cycle itself.

Model 1 replicates DGW for the period 1977-1986, using newly collected data. I used instruments and specifications published in the original DGW article. The next model, Model 2, relies on the time period from 1988-2001, using IRS source data for the audit rate in later years merged with IRS Data Book audit rates, where available. Notable in this model is the switch in time periods covered and instruments employed. As the table shows, the IRS budget per return filed is a very significant factor in determining the audit rate (see the reduced form equation reported under Model 2 for the variable, IAR2). Also, the instrument for exam time devoted to direct examination is significant and positive in the audit reduced form. This finding implies that in districts and time periods with larger resources devoted a priori to examination, the audit rate is higher. This result is clearly logical and was expected. The revised model shows that audit rates remain statistically significant. I previously discussed the changes in sign in some previously significant factors such as the percentage of employed persons in manufacturing and service industries. Another very significant change in results concerns the effect of audit rates on filings. Previously, DGW had found that an increase in audits would lead to fewer returns filed.

As discussed in DGW, the relationship between socioeconomic, tax base, and tax compliance factors and the number of returns filed may be quite complex. With respect to variables that relate to taxpayers' compliance, DGW argued that taxpayers confront three 
options: (1) to file a return and report honestly; (2) to file a return and underreport taxes; (3) or not to file a return. Anything that reduces the benefits or increases the costs of filing a return and underreporting taxes will increase the likelihood that a given taxpayer chooses to (1) file a return and report honestly or (2) not file a return. We called this the compliance principle. DGW argued that the compliance principle would apply very strongly to the federal audit rate because increases in the federal audit rate decrease the benefits and increase the costs of filing a return and underreporting taxes due. DGW expected (and found) that an increase in the audit rate decreased returns filed per capita. My results for the post-1987 period seemingly contradict the findings of DGW pre-1988. However, the compliance principle predicts that either returns filed would decline or returns filed would increase with greater compliance. My results indicate that the latter situation is now in effect - increases in the audit rate lead to greater levels of compliance and a greater number of honestly prepared returns.

In Model 3, the audit rate from the IRS Data Books is replaced with the combined rate for revenue agent and tax agent audits. The results indicate that the selected instruments are significant factors in the reduced form for the audit rate and that the estimated audit effect is positive and statistically significant.

In Model 4, I add the factor for correspondence audits to the previous specification. Interestingly, the significance of AUDR12 (the combined audit rate for revenue agents and tax agents) and of AUDR5 (the correspondence audit rate) is now lost. There is a large change in the estimated magnitude of the coefficients, which suggests that collinearity issues are again present. Pursuing this set of models, I then split the combined audit rate for revenue agents and tax agents into separate factors for each type of audit. This model (Model 5) again reveals general insignificance of these separate factors. ${ }^{23}$ Additionally, in this specification, the revenue agent audit effect is no longer positively associated with compliance. Given that the simplest of these specifications showed a significant and positive audit effect (paralleling results from the longer time periods), the more refined audit models do not provide useful results.

\footnotetext{
${ }^{23}$ This model requires the use of a third instrument as discussed above.
} 
Next, I examine models selected to measure CI effects. In Model 6, I include factors for tax sentences ( $\mathrm{T}$ ) and money laundering sentences (M). This model demonstrates that money laundering sentences have a statistically significant effect on tax compliance.

Model 7 investigates the sentencing form of the explanatory factors from the previous model. Here, I introduce variables for: (1) the percentage of tax sentences resulting in prison time; (2) the percentage of tax sentences resulting in probation; (3) the percentage of money laundering sentences resulting in prison time; and (4) the percentage of money laundering sentences resulting in probation. These factors do not diminish the available degrees of freedom, and the estimates are performed for the same period 1988 through 2001 as in Model 6. This specification fails to indicate statistical significance of tax sentences or of the various percentages of such cases that result in prison or probation. However, money laundering cases remain statistically significant in their effects on compliance. Further, the percentage of money laundering cases that result in prison terms raises the compliance level. However, an increase in the percentage of money laundering cases resulting in probation does not increase compliance. ${ }^{24}$

Turning to media, I added factors for the percentage of tax and money laundering cases that result in any form of media attention (TMD_T and MMD_M) to the specification that included the total number of tax and money laundering sentences. The resulting model is Model 8. Since media information was available only after 1992, this resulted in losing 200 observations (50 states, 4 years). In these models, the basic variables for tax and money laundering sentenced cases become insignificant. These results appear to contradict the findings in the models with more observations. Therefore, I reject their significance.

In Table 2, I aggregate prison and probation cases and consider a factor for the percentage of sentenced cases not receiving prison or probation. The results of these specifications are presented in Table 2. I modify Model 7 by replacing the factors for prison and probation rates in tax and money laundering sentences with variables for the percentage of tax and money laundering sentences receiving neither prison nor probation (Model 9). As was the

\footnotetext{
${ }^{24}$ The percentage of tax or money laundering cases not resulting in prison or probation was also not statistically significant in these models.
} 
case in Model 7, the variable for counts of money laundering sentences is statistically significant. In addition, the percentage of money laundering cases receiving neither prison nor probation has a significantly negative effect on compliance. The audit rate effects are also consistently positive and significant.

Model 10 combines the tax and money laundering sentences into a single explanatory factor. This variable reveals statistical significance. However, the percentages of cases that are tax or money laundering cases are statistically insignificant. (The coefficients indicate that the higher percentage of tax cases vs. money laundering cases is of greater significance.) Model 11 adds the sentencing effect and reveals that sentenced cases that receive neither prison nor probation are negatively associated with compliance. Finally, Model 12 combines all CI cases (tax, money laundering, and other) into a single explanatory factor. I find that this factor is also statistically significant in its effect on compliance.

I conclude from these final specifications that CI activity has a statistically significant and demonstrable effect on tax compliance. However, while I have found that sentenced cases that do not receive prison time or probation lead to lower compliance levels, I am not able to find a specific mix of tax and money laundering cases that would raise compliance over existing levels. The percentages of these cases with respect to total sentences did not have statistically significant effects on compliance. ${ }^{25}$

\section{V.2 SIMULATIONS}

I performed two basic simulations to determine the direct revenue (spillover) effect of audits. Following the methodology established in DGW, I calculated a predicted value for the increase in total assessed liability for a particular year that would have resulted from holding audit rates at their earlier period (higher) levels. I also calculated the effect of this audit rate change on reported liabilities (excluding additional taxes and penalties resulting from IRS examinations). The difference between the two estimates represents the direct revenue effect of

\footnotetext{
${ }^{25}$ The shortened time period available to study media effects on the subcomponent of examinations did not allow me to precisely measure these effects. Given the large general deterrence effect found for CI activities, there is indirect evidence of a large media effect, even if the econometric model did not have sufficient data to isolate this result.
} 
the increase in audit rates. DGW estimated that the spillover effects of audits produce six out of every seven dollars of additional revenue.

In these simulations, a change in the audit rate (and later the levels of CI activity) leads to two measurable effects. First, the change in audit rate causes assessed liabilities to increase and reported liabilities to increase. Let dALR denote the change in assessed liability per return for a change in the audit rate of dIAR. Similarly, let dRTR denote the change in reported tax liability per return for the same change in audit rate dIAR. DGW called the change dALR the total revenue effect (since it includes both reported amounts and additional taxes and penalties) and dRTR the indirect effect. The direct effect of audits is defined as dALR-dRTR. Since ALR-RTR is a measure of additional taxes and penalties, dALR-dRTR is simply the change in additional tax and penalties resulting from the audit change. Consequently, it is the direct effect. DGW defined the spillover measure as the ratio dRTR/dALR since it measures the percentage of the total change that occurs from general deterrence as a result of the change in the audit rate. ${ }^{26}$

I considered several experiments. In some cases, I doubled individual components such as the audit rate. Similarly, I considered doubling the number of tax sentences or doubling the number of money laundering sentences. In some cases, I doubled both the number of tax and money laundering cases. For variables measured in percentages (such as the percentage of money laundering cases that received prison sentences), I increased the percentage by 25 percent absolutely. Noticing in some cases that certain variables had statistically insignificant coefficients, I experimented with the same model but only increased the levels of the significant variables (generally the money laundering components).

\footnotetext{
${ }^{26}$ The simulations rely on two simultaneous predicted changes in all cases. As I discussed, the simulation affects the level of assessed liabilities per return filed or reported liabilities per return filed. However, the simulation also affects the estimated number of returns filed per capita. In conjunction with estimates of population (and after conversion from real to nominal terms), the product of population, predicted returns per capita, and collections per return filed yields the final dollar figures in the tables. Hence, in some cases, the sign on a single variable in a model is not sufficient to understand the overall significance of increasing one or more components in the model.
} 
The simulations are provided in Table 3. For example, consider the simulation in which audit rates are doubled. The first row in Model 11 of Table 3 shows that for Model 11 estimated assessed tax collections would rise to $\$ 959.1$ billion from $\$ 940.4$ billion in 2001 . The change of $\$ 18.706$ billion is the total revenue effect. The estimates also show that reported tax collections rise by $\$ 17.571$ billion. This change is the indirect effect of doubling the audit rate. The difference between these two estimated differences is approximately $\$ 1.135$ billion and represents the direct revenue effect. This amount is 93.9 percent of the total revenue effect.

Doubling CI activity (tax and money laundering cases) leads to $\$ 15.698$ billion in increased reported taxes, $\$ 16.68$ billion in increased per annum assessed tax revenue, and a direct revenue increase of $\$ 0.982$ billion. Hence, the spillover effect is measured to be approximately $94 \%$. Importantly, doubling CI activity or doubling the IRS audit examination rate leads to similar revenue increases and implies similar levels of increased general deterrence.

As seen in Table 3, the estimated spillover effects are large but depend to some degree on the model. The calculation of confidence intervals for the simulations conducted in our study are complicated for several reasons. First, total reported taxes due rise as the product of collections per return and returns filed per capita. Audit and enforcement effects are present in both equations for these variables. Further complications arise due to the dynamics in the models, the conversion from real to nominal terms, and the adjustment from per capita to total dollars. An alternate procedure is to simulate the audit/enforcement experiments using estimated coefficients that are one or two standard errors different from the estimated values. We have followed this procedure for our main simulation results.

For simulations in which the audit rate is doubled, I find that a 90 percent lower bound on the estimated increase in reported taxes is $\$ 11.468$ billion. A similar lower bound on the estimated increase in assessed tax revenue is $\$ 12.578$ billion. At the lower bound estimates, the spillover effect is 91.2 percent. For simulations in which CI enforcement levels are doubled, I find that a 90 percent lower bound on the estimated increase in reported taxes is $\$ 3.348$ billion. A similar lower bound on the estimated increase in assessed tax revenue is $\$ 4.309$ billion. At the lower bound estimates, the spillover effect is 77.7 percent. There are two important conclusions 
from this analysis. First, the spillover effect of audits and CI enforcement is quite large and generally estimated to be over 90 percent. Second, an increase in IRS examination activity could have important fiscal impacts and make a large contribution toward reducing the tax gap. However, there is no evidence, in our study, that correspondence audits have made up for the decline in face-to-face tax audits. This result may be due to the limited time period during which we were able to measure the correspondence audit rate.

\section{CONCLUSIONS}

I now summarize my results and answer the basic questions that were posed in this project. First, I find that $\mathrm{CI}$ activities have a measurable effect on voluntary compliance. I have found statistically significant results from my measure of CI sentenced cases on general tax deterrence. Second, I conclude that the mix of sentenced cases (tax and money laundering) is not a significant determinant of tax compliance (perhaps because the mix has been already optimally set). Third, media attention shows some weak evidence of increasing compliance, at least among money laundering cases. However, it is logical to think that media attention plays an important role in disseminating information to the public. The range of media attention or the time span that we studied may have been too limited or too short to detect the media's role. At present, my results are not refined enough to distinguish types of media coverage. Nevertheless, the significant magnitude of general deterrence results implies that media plays a large role in CI cases. Finally, I have found that incarceration and probation (rather than fines) have the most influence on taxpayers. It would seem that an emphasis on prison and probation time should be encouraged based on these results.

It is not too speculative to suggest that the IRS could double its audit rate without doubling its organizational size. Clearly, the IRS has not shrunk in size in the same proportion that audits have declined. Conversely, doubling CI activities might easily necessitate economically and physically doubling the resources devoted to CI. CI has never sentenced a number of cases represented by doubling of its current load. According to estimates reported by Plumley (1996, Table 5, pp. 41), the cost for a CI conviction was nearly 80 times more expensive than an audit in 1991. While these unit costs are unlikely to apply to doubling CI activity, we can get some idea of the dollar magnitude of these simulations using Plumley's reported figures. 
In 1991, Plumley reported a unit cost of $\$ 1,298$ per audit and a unit cost of $\$ 103,064$ per CI conviction. These are $\$ 1,597$ and $\$ 126,801$ in 2001 after adjusting for inflation. In the same year, there were approximately 202,244 individual audits performed and only roughly 2000 tax and money laundering sentences. Plumley's estimates of unit costs include overhead, support, and follow-on costs.

Doubling tax and money laundering sentences would cost \$254 million (at these unit cost estimates), while doubling the audit rate would cost $\$ 323$ million. However, doubling the audit rates is predicted to lead to an $\$ 18.71$ billion increase in per annum reported collections, while doubling tax and money laundering cases was predicted to increase reported tax collection by \$16.68 billion per annum. Hence, an additional dollar allocated to audit would return $\$ 58$ in general deterrence ${ }^{27}$, while an additional dollar allocated to CI would result in $\$ 66$. Thus, there is some evidence that resources between civil and criminal enforcement at the IRS have been misallocated, with CI's activities receiving too few resources. This difference is not statistically different from zero. A 90 percent lower bound on additional reported collections per dollar cost is $\$ 39$ for the doubled audit rate simulation and $\$ 17$ for the doubled CI activities simulation.

However, as I mentioned above, it is unlikely that CI could double its activity level without incurring substantially greater costs than these marginal (per unit) estimates imply. Moreover, the larger the increase in CI activity we simulate through the model, the less reliable the estimates become if we move away from measurable historical experience. Doubling CI activity is very different from doubling the individual audit rate, since CI has never operated at twice its current size. Conversely, doubling the individual audit rate is within the IRS' historical experience.

Still, an increase in the IRS budget of \$25 million allocated to CI for additional investigations, prosecutions, and sentencing would not appear to push the envelope of historical experience. Such an amount might be used to increase tax and money laundering cases by

\footnotetext{
${ }^{27}$ Plumley's (1991) estimate of the return to audits was similar. He found a marginal indirect revenue to cost ratio of 55 .
} 
roughly 200 per year. This represents a roughly 10 percent increase in tax and money laundering cases at 2001 levels. But, more important, this increase is within the range of historical CI experience. According to the simulations, general deterrence would rise by nearly $\$ 1.7$ billion as a result of the $\$ 25$ million allocation to cases processed by CI. With fixed budgets, a cost savings of this magnitude allocated to prosecutions and sentences could achieve the same result if efficiency and productivity gains could be achieved. 
TABLE 1

\begin{tabular}{|c|c|c|c|c|c|c|c|c|c|c|c|c|}
\hline \multirow{2}{*}{ VARIABLE } & \multicolumn{4}{|c|}{ MODEL 1} & \multicolumn{4}{|c|}{ MODEL 2} & \multicolumn{4}{|c|}{ MODEL 3} \\
\hline & ALR & RTR & RCAP & IAR & ALR & RTR & RCAP & IAR2 & ALR & RTR & RCAP & AUDR12 \\
\hline Constant & $\begin{array}{r}0.59 \\
(2.94)\end{array}$ & $\begin{array}{r}0.55 \\
(2.77)\end{array}$ & $\begin{array}{r}303.24 \\
(10.18)\end{array}$ & $\begin{array}{r}0.89 \\
(1.57)\end{array}$ & $\begin{array}{r}0.24 \\
(0.70)\end{array}$ & $\begin{array}{r}0.27 \\
(0.79)\end{array}$ & $\begin{array}{r}180.34 \\
(5.13) \\
\end{array}$ & $\begin{array}{r}2.14 \\
(3.37)\end{array}$ & $\begin{array}{r}1.50 \\
(3.55)\end{array}$ & $\begin{array}{r}1.53 \\
(3.65)\end{array}$ & $\begin{array}{r}169.02 \\
(3.49) \\
\end{array}$ & $\begin{array}{r}(0.21) \\
(-0.33)\end{array}$ \\
\hline $\begin{array}{l}\text { Percent of Families on } \\
\text { Welfare }\end{array}$ & $\begin{array}{r}-0.00023 \\
(-0.03)\end{array}$ & $\begin{array}{r}0.00089 \\
(0.13)\end{array}$ & $\begin{array}{r}0.67656 \\
(0.69)\end{array}$ & $\begin{array}{r}0.03000 \\
(1.47)\end{array}$ & $\begin{array}{r}0.01515 \\
(1.85)\end{array}$ & $\begin{array}{r}0.01430 \\
(1.76)\end{array}$ & $\begin{array}{r}-0.47104 \\
(-0.66)\end{array}$ & $\begin{array}{r}0.05970 \\
(4.16)\end{array}$ & $\begin{array}{r}0.00780 \\
(0.75)\end{array}$ & $\begin{array}{r}0.00750 \\
(0.72)\end{array}$ & $\begin{array}{r}-1.65160 \\
(-1.49)\end{array}$ & $\begin{array}{r}0.09530 \\
(7.97)\end{array}$ \\
\hline State Tax Rate & $\begin{array}{r}-0.0144 \\
(-1.72)\end{array}$ & $\begin{array}{r}-0.0149 \\
(-1.79)\end{array}$ & $\begin{array}{r}-3.4992 \\
(-2.87)\end{array}$ & $\begin{array}{l}-0.047 \\
(-1.95)\end{array}$ & $\begin{array}{r}-0.0042 \\
(-0.66)\end{array}$ & $\begin{array}{r}-0.0041 \\
(-0.64)\end{array}$ & $\begin{array}{r}-2.2240 \\
(-2.84)\end{array}$ & $\begin{array}{r}-0.0120 \\
(-0.98)\end{array}$ & $\begin{array}{r}-0.0250 \\
(-3.02)\end{array}$ & $\begin{array}{r}-0.0260 \\
(-3.05)\end{array}$ & $\begin{array}{r}-0.1850 \\
(-0.14)\end{array}$ & $\begin{array}{r}-0.0180 \\
(-1.45)\end{array}$ \\
\hline Personal Income Per Capita & $\begin{array}{r}0.254 \\
(16.88)\end{array}$ & $\begin{array}{r}0.250 \\
(16.79)\end{array}$ & $\begin{array}{r}15.149 \\
(6.76)\end{array}$ & $\begin{array}{r}-0.244 \\
(-5.9)\end{array}$ & $\begin{array}{r}0.338 \\
(18.19)\end{array}$ & $\begin{array}{r}0.339 \\
(18.31)\end{array}$ & $\begin{array}{r}11.608 \\
(6.07)\end{array}$ & $\begin{array}{l}-0.134 \\
(-4.24)\end{array}$ & $\begin{array}{r}0.314 \\
(16.54)\end{array}$ & $\begin{array}{r}0.315 \\
(16.65)\end{array}$ & $\begin{array}{r}16.149 \\
(7.38)\end{array}$ & $\begin{array}{l}-0.084 \\
(-3.17)\end{array}$ \\
\hline Family Size & $\begin{array}{l}-0.690 \\
(-1.26)\end{array}$ & $\begin{array}{l}-0.679 \\
(-1.23)\end{array}$ & $\begin{array}{r}-105.775 \\
(-1.38)\end{array}$ & $\begin{array}{l}-2.308 \\
(-1.42)\end{array}$ & $\begin{array}{l}-2.220 \\
(-2.18)\end{array}$ & $\begin{array}{l}-2.318 \\
(-2.29)\end{array}$ & $\begin{array}{r}578.597 \\
(5.9)\end{array}$ & $\begin{array}{r}1.131 \\
(0.6)\end{array}$ & $\begin{array}{l}-0.355 \\
(-0.35)\end{array}$ & $\begin{array}{l}-0.454 \\
(-0.45)\end{array}$ & $\begin{array}{r}349.885 \\
(3.13)\end{array}$ & $\begin{array}{l}1.061 \\
(0.72)\end{array}$ \\
\hline Farms Per Household & $\begin{array}{r}-3.98 \\
(-4.46)\end{array}$ & $\begin{array}{r}-3.97 \\
(-4.55)\end{array}$ & $\begin{array}{r}-270.12 \\
(-1.92)\end{array}$ & $\begin{array}{r}-5.19 \\
(-1.97)\end{array}$ & $\begin{array}{r}0.63 \\
(0.31)\end{array}$ & $\begin{array}{l}0.82 \\
(0.4)\end{array}$ & $\begin{array}{r}-191.74 \\
(-0.59)\end{array}$ & $\begin{array}{r}3.86 \\
(1.01)\end{array}$ & $\begin{array}{r}-3.96 \\
(-1.62)\end{array}$ & $\begin{array}{r}-3.79 \\
(-1.55)\end{array}$ & $\begin{array}{l}-87.30 \\
(-0.23)\end{array}$ & $\begin{array}{r}7.12 \\
(1.99)\end{array}$ \\
\hline $\begin{array}{l}\text { Percent of Adults with High } \\
\text { School Diploma }\end{array}$ & $\begin{array}{r}-0.16 \\
(-1.08)\end{array}$ & $\begin{array}{r}-0.09 \\
(-0.59)\end{array}$ & $\begin{array}{r}143.64 \\
(6.11)\end{array}$ & $\begin{array}{r}3.12 \\
(7.87)\end{array}$ & $\begin{array}{r}-0.68 \\
(-4.93)\end{array}$ & $\begin{array}{r}-0.69 \\
(-5.04)\end{array}$ & $\begin{array}{r}30.17 \\
(2.5)\end{array}$ & $\begin{array}{r}-1.19 \\
(-4.56)\end{array}$ & $\begin{array}{r}-1.93 \\
(-6.56)\end{array}$ & $\begin{array}{r}-1.94 \\
(-6.63)\end{array}$ & $\begin{array}{l}90.58 \\
(2.85)\end{array}$ & $\begin{array}{r}0.28 \\
(0.64)\end{array}$ \\
\hline Percent of Pop Over 65 & $\begin{array}{r}-0.27 \\
(-0.56) \\
\end{array}$ & $\begin{array}{r}-0.20 \\
(-0.41) \\
\end{array}$ & $\begin{array}{r}-129.67 \\
(-1.76)\end{array}$ & $\begin{array}{r}-0.85 \\
(-0.61) \\
\end{array}$ & $\begin{array}{r}2.58 \\
(2.32)\end{array}$ & $\begin{array}{r}2.62 \\
(2.36) \\
\end{array}$ & $\begin{array}{r}-397.95 \\
(-2.87) \\
\end{array}$ & $\begin{array}{r}-7.81 \\
(-4) \\
\end{array}$ & $\begin{array}{r}0.57 \\
(0.45)\end{array}$ & $\begin{array}{l}0.63 \\
(0.5) \\
\end{array}$ & $\begin{array}{r}-327.82 \\
(-1.84)\end{array}$ & $\begin{array}{r}-4.15 \\
(-2.27) \\
\end{array}$ \\
\hline $\begin{array}{l}\text { Percent of Employed Persons } \\
\text { in Manufacturing }\end{array}$ & $\begin{array}{r}0.08 \\
(0.49)\end{array}$ & $\begin{array}{r}0.11 \\
(0.66)\end{array}$ & $\begin{array}{l}47.40 \\
(1.81)\end{array}$ & $\begin{array}{r}0.81 \\
(1.68)\end{array}$ & $\begin{array}{r}-1.00 \\
(-2.98)\end{array}$ & $\begin{array}{r}-1.00 \\
(-2.99)\end{array}$ & $\begin{array}{r}211.38 \\
(5.56)\end{array}$ & $\begin{array}{r}-0.55 \\
(-0.86)\end{array}$ & $\begin{array}{r}-0.25 \\
(-0.6)\end{array}$ & $\begin{array}{r}-0.25 \\
(-0.6)\end{array}$ & $\begin{array}{r}141.15 \\
(2.52)\end{array}$ & $\begin{array}{r}-0.28 \\
(-0.44)\end{array}$ \\
\hline $\begin{array}{l}\text { Percent of Employed Persons } \\
\text { in Service }\end{array}$ & $\begin{array}{r}-1.72 \\
(-6.32)\end{array}$ & $\begin{array}{r}-1.77 \\
(-6.62)\end{array}$ & $\begin{array}{r}211.93 \\
(4.9)\end{array}$ & $\begin{array}{r}0.88 \\
(1.06)\end{array}$ & $\begin{array}{r}0.36 \\
(0.88)\end{array}$ & $\begin{array}{r}0.37 \\
(0.92)\end{array}$ & $\begin{array}{r}8.76 \\
(0.22)\end{array}$ & $\begin{array}{r}0.75 \\
(0.99)\end{array}$ & $\begin{array}{r}-0.43 \\
(-0.84)\end{array}$ & $\begin{array}{r}-0.43 \\
(-0.85)\end{array}$ & $\begin{array}{r}-1.81 \\
(-0.03)\end{array}$ & $\begin{array}{r}0.69 \\
(0.92)\end{array}$ \\
\hline Unemployment Rate & $\begin{array}{r}-0.95 \\
(-3.49)\end{array}$ & $\begin{array}{l}-0.97 \\
(-3.5)\end{array}$ & $\begin{array}{r}-311.01 \\
(-8.67)\end{array}$ & $\begin{array}{r}-2.88 \\
(-3.44)\end{array}$ & $\begin{array}{r}-3.11 \\
(-5.51)\end{array}$ & $\begin{array}{r}-3.13 \\
(-5.59)\end{array}$ & $\begin{array}{r}-185.50 \\
(-4.02)\end{array}$ & $\begin{array}{r}-0.44 \\
(-0.42)\end{array}$ & $\begin{array}{r}-6.83 \\
(-9.33)\end{array}$ & $\begin{array}{r}-6.84 \\
(-9.39)\end{array}$ & $\begin{array}{r}-171.18 \\
(-2.31)\end{array}$ & $\begin{array}{r}1.94 \\
(1.74)\end{array}$ \\
\hline Dummy (Year>1980) & $\begin{array}{l}0.069 \\
(5.14)\end{array}$ & $\begin{array}{l}0.063 \\
(4.57)\end{array}$ & $\begin{array}{r}-0.853 \\
(-0.5)\end{array}$ & $\begin{array}{l}0.010 \\
(0.25)\end{array}$ & -- & - & -- & - & -- & - & - & $\ldots$ \\
\hline Audit Rate & $\begin{array}{r}0.12 \\
(5.05)\end{array}$ & $\begin{array}{r}0.11 \\
(4.59)\end{array}$ & $\begin{array}{l}-14.25 \\
(-4.22)\end{array}$ & - & $\begin{array}{r}0.15 \\
(3.42)\end{array}$ & $\begin{array}{r}0.13 \\
(3.13)\end{array}$ & $\begin{aligned} 16.15 \\
(4.44)\end{aligned}$ & - & -- & -- & -- & - \\
\hline Audit Rate (Revenue Agents) & -- & -. & -- & - & -- & .- & - & .- & .. & .- & $\ldots$ & $\ldots$ \\
\hline $\begin{array}{l}\text { Audit Rate (Revenue } \\
\text { Agents+Tax Auditors) }\end{array}$ & .- & .- & $\ldots$ & - & .. & - & - & - & $\begin{array}{l}0.117 \\
(2.16)\end{array}$ & $\begin{array}{l}0.097 \\
(1.81)\end{array}$ & $\begin{array}{r}35.625 \\
(6.42)\end{array}$ & . \\
\hline Audit Rate (Tax Auditors) & -- & .- & -- & - & .- & .- & - & - & -. & .- & $\ldots$ & $\ldots$ \\
\hline Audit Rate (Service Centers) & -- & - & - & - & - & - & - & - & .. & -- & $\ldots$ & - \\
\hline Total Sentences & -. & -- & - & - & -- & -- & - & -- & $\ldots$ & - & $\ldots$ & $\ldots$ \\
\hline Tax Sentences & - & -- & - & - & -- & - & - & - & -- & - & - & - \\
\hline Money Laundering Sentences & - & -- & - & - & - & -- & - & - & - & -- & - & - \\
\hline $\begin{array}{l}\text { Percent of Tax Sentences in } \\
\text { Media }\end{array}$ & -. & .. & -. & - & .. & -. & -- & $\ldots$ & .. & .- & .- & $\ldots$ \\
\hline $\begin{array}{l}\text { Percent of Money Laundering } \\
\text { Sentences in Media }\end{array}$ & -- & -- & -- & - & - & -. & - & - & -- & -. & -- & - \\
\hline \begin{tabular}{|l} 
Percent of Tax Sentences \\
Resulting in Prison
\end{tabular} & -. & .- & - & - & -. & - & -- & - & - & - & - & $\ldots$ \\
\hline $\begin{array}{l}\text { Percent of Tax Sentences } \\
\text { Resulting in Probation }\end{array}$ & $\ldots$ & $\ldots$ & - & - & .- & .- & -- & - & -- & .- & -- & $\ldots$ \\
\hline $\begin{array}{l}\text { Percent of Money Laun Sent } \\
\text { Resulting in Prison }\end{array}$ & -- & .- & -- & - & .- & .. & - & - & .- & .. & $\ldots$ & $\ldots$ \\
\hline $\begin{array}{l}\text { Percent of Money Laun Sent } \\
\text { Resulting in Probation }\end{array}$ & $\ldots$ & .. & .- & - & .. & .. & .- & $\ldots$ & .. & ... & $\ldots$ & .. \\
\hline $\begin{array}{l}\text { Info returns not W2 filed / tot } \\
\text { number of info returns filed }\end{array}$ & - & - & - & $\begin{array}{l}-0.133 \\
(-9.45)\end{array}$ & - & -- & - & - & - & - & - & \\
\hline Direct Examination Time & -- & .- & -- & & .- & .. & - & $\begin{array}{l}1.019 \\
(5.26)\end{array}$ & .- & .. & $\ldots$ & $\begin{array}{r}1.229 \\
(8.1)\end{array}$ \\
\hline Budget Per Return & -- & - & - & $\begin{array}{r}258.945 \\
(10.89) \\
\end{array}$ & - & - & - & $\begin{array}{l}24.447 \\
(10.19) \\
\end{array}$ & - & - & - & $\begin{array}{r}16.094 \\
(7.97) \\
\end{array}$ \\
\hline $\begin{array}{l}\text { State Government Ideology } \\
\text { (100 is most liberal) }\end{array}$ & -_ & .- & -- & - & .- & .- & -- & - & .- & -. & -- & 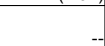 \\
\hline
\end{tabular}

DGW2: obsno $=500$ years: $1977-1986$

DGW_IAR2A: obsno=700 years: $1988-2001$

DGW93_12,5: obsno $=450$ years: $1993-2001$

DGW93 1,2,5: obsno $=450$ years: $1993-2001$

DGW_TM1: obsno $=700$ years: $1988-2001$

DGW_TM3: obsno $=700$ years: $1988-2001$

DGW-MD1: obsno $=500$ years: $1992-2001$ 


\section{TABLE 1 (cont.)}

\begin{tabular}{|c|c|c|c|c|c|c|c|c|c|c|c|c|c|c|c|}
\hline \multirow{2}{*}{ VARIABLE } & \multicolumn{5}{|c|}{ MODEL 4} & \multicolumn{6}{|c|}{ MODEL 5} & \multicolumn{4}{|c|}{ MODEL 6} \\
\hline & ALR & RTR & RCAP & AUDR12 & AUDR5 & ALR & RTR & RCAP & AUDR1 & AUDR2 & AUDR5 & ALR & RTR & RCAP & IAR2 \\
\hline Constant & $\begin{array}{r}9.91 \\
(0.26)\end{array}$ & $\begin{array}{r}9.80 \\
(0.26)\end{array}$ & $\begin{array}{r}1817.36 \\
(0.22)\end{array}$ & \begin{tabular}{r|}
$(0.33)$ \\
$(-0.46)$
\end{tabular} & $\begin{array}{r}(10.99) \\
(-1.72)\end{array}$ & \begin{tabular}{r|}
0.90 \\
$(0.57)$
\end{tabular} & $\begin{array}{r}0.95 \\
(0.61)\end{array}$ & $\begin{array}{r}201.06 \\
(0.82)\end{array}$ & $\begin{array}{r}0.09 \\
(0.23)\end{array}$ & $\begin{array}{r}(0.40) \\
(-0.88)\end{array}$ & $\begin{array}{r}(9.25) \\
(-1.51)\end{array}$ & $\begin{array}{l}0.20 \\
(0.6)\end{array}$ & $\begin{array}{r}0.24 \\
(0.69)\end{array}$ & $\begin{array}{r}188.76 \\
(5.42)\end{array}$ & $\begin{array}{r}2.13 \\
(3.4)\end{array}$ \\
\hline $\begin{array}{l}\text { Percent of Families on } \\
\text { Welfare }\end{array}$ & -0.233 & -0.227 & -68.993 & 0.098 & 0.274 & 0.067 & 0.065 & 7.407 & 0.043 & 0.054 & 0.266 & 0.01087 & 0.01026 & -0.24503 & 0.05970 \\
\hline & $(-0.21)$ & $(-0.21)$ & $(-0.21)$ & (7.6) & (2.37) & $(1.07)$ & $(1.06)$ & $(0.78)$ & (6.27) & (6.48) & (2.35) & (1.31) & (1.24) & $(-0.34)$ & (4.09) \\
\hline State Tax Rate & $\begin{array}{r}-0.1246 \\
(-0.28)\end{array}$ & $\begin{array}{r}-0.1211 \\
(-0.28)\end{array}$ & $\begin{array}{r}-36.35 \\
(-0.2)\end{array}$ & $\begin{array}{r}-0.0210 \\
(-1.12)\end{array}$ & $\begin{array}{r}0.1250 \\
(0.75)\end{array}$ & $\begin{array}{r}-0.0219 \\
(-0.81)\end{array}$ & $\begin{array}{r}-0.0225 \\
(-0.86)\end{array}$ & $\begin{array}{r}-1.2784 \\
(-0.31)\end{array}$ & $\begin{array}{r}-0.0070 \\
(-0.78)\end{array}$ & $\begin{array}{r}-0.0130 \\
(-1.2)\end{array}$ & $\begin{array}{r}0.1430 \\
(0.98)\end{array}$ & $\begin{array}{r}-0.0034 \\
(-0.54)\end{array}$ & \begin{tabular}{r|}
-0.0032 \\
$(-0.52)$
\end{tabular} & $\begin{array}{r}-2.3815 \\
(-3.09)\end{array}$ & $\begin{array}{r}-0.0120 \\
(-1.08)\end{array}$ \\
\hline Personal Income Per Capita & $\begin{array}{r}0.326 \\
(1.4)\end{array}$ & $\begin{array}{l}0.325 \\
(1.45)\end{array}$ & $\begin{array}{l}30.70 \\
(0.36)\end{array}$ & $\begin{array}{l}-0.079 \\
(-2.58)\end{array}$ & $\begin{array}{l}0.024 \\
(0.09)\end{array}$ & $\begin{array}{l}0.255 \\
(4.38)\end{array}$ & $\begin{array}{l}0.058 \\
(4.52)\end{array}$ & $\begin{array}{l}2.485 \\
(0.28)\end{array}$ & $\begin{array}{r}-0.055 \\
(-3.4)\end{array}$ & $\begin{array}{r}-0.027 \\
(-1.4)\end{array}$ & $\begin{array}{l}0.043 \\
(0.16)\end{array}$ & \begin{tabular}{r|}
0.335 \\
$(18.35)$
\end{tabular} & \begin{tabular}{r|}
0.336 \\
$(18.46)$
\end{tabular} & $\begin{array}{r}11.874 \\
(6.26)\end{array}$ & $\begin{array}{r}T .0 .131 \\
(-4.21)\end{array}$ \\
\hline Family Size & $\begin{array}{r}-16.755 \\
(-0.22)\end{array}$ & $\begin{array}{r}1.4 U 7 \\
-16.577 \\
(-0.22)\end{array}$ & $\begin{array}{r}-2582.63 \\
(-0.17)\end{array}$ & $\begin{array}{r}1.830 \\
(1.14)\end{array}$ & $\begin{array}{r}20.874 \\
(1.45)\end{array}$ & $\begin{array}{l}0.451 \\
(0.14)\end{array}$ & $\begin{array}{r}0.330 \\
(0.1)\end{array}$ & $\begin{array}{r}139.855 \\
(0.28)\end{array}$ & $\begin{array}{l}-0.047 \\
(-0.06)\end{array}$ & $\begin{array}{l}1.630 \\
(1.58)\end{array}$ & $\begin{array}{r}18.579 \\
(1.32)\end{array}$ & $\begin{array}{r}-1.754 \\
(-1.74)\end{array}$ & $\begin{array}{r}-1.854 \\
(-1.85)\end{array}$ & $\begin{array}{r}529.818 \\
(5.33)\end{array}$ & $\begin{array}{r}1.005 \\
(0.54)\end{array}$ \\
\hline Farms Per Household & $\begin{array}{r}-5.63 \\
(-0.12)\end{array}$ & $\begin{array}{r}-5.12 \\
(-0.11)\end{array}$ & $\begin{array}{r}-660.72 \\
(-0.08)\end{array}$ & $\begin{array}{r}10.70 \\
(1.93)\end{array}$ & $\begin{array}{r}4.03 \\
(0.08)\end{array}$ & $\begin{array}{r}-3.58 \\
(-0.59)\end{array}$ & $\begin{array}{r}-3.25 \\
(-0.54)\end{array}$ & $\begin{array}{r}-656.14 \\
(-0.67)\end{array}$ & $\begin{array}{r}1.01 \\
(0.39)\end{array}$ & $\begin{array}{r}8.15 \\
(2.6)\end{array}$ & $\begin{array}{r}0.02 \\
(0)\end{array}$ & $\begin{array}{r}0.37 \\
(0.19)\end{array}$ & $\begin{array}{r}0.54 \\
(0.27)\end{array}$ & $\begin{array}{r}-130.62 \\
(-0.42)\end{array}$ & $\begin{array}{r}3.81 \\
(1.02)\end{array}$ \\
\hline $\begin{array}{l}\text { Percent of Adults with High } \\
\text { School Diploma }\end{array}$ & $\begin{array}{r}-0.79 \\
(-0.12)\end{array}$ & $\begin{array}{r}-0.80 \\
(-0.12)\end{array}$ & $\begin{array}{r}141.47 \\
(0.14)\end{array}$ & $\begin{array}{r}0.30 \\
0633\end{array}$ & $\begin{array}{r}-1.66 \\
-1.46 \\
\end{array}$ & $\begin{array}{r}-1.10 \\
-1.9\end{array}$ & $\begin{array}{r}-1.15 \\
(1.27\end{array}$ & $\begin{array}{l}353.58 \\
\end{array}$ & 0.57 & $\begin{array}{r}-0.27 \\
-0.27 \\
\end{array}$ & -1.66 & $\begin{array}{r}-0.73 \\
-511\end{array}$ & $\begin{array}{r}-0.74 \\
\end{array}$ & 35.84 & $\begin{array}{r}-1.18 \\
(-4.4)\end{array}$ \\
\hline Percent of Pop Over 65 & $\begin{array}{r}-7.58 \\
(-0.19)\end{array}$ & $\begin{array}{r}-7.60 \\
(-0.19)\end{array}$ & $\begin{array}{r}-1168.83 \\
(-0.19)\end{array}$ & $\begin{array}{r}-5.61 \\
(-2.21)\end{array}$ & 12.34 & \begin{tabular}{r|}
1.88 \\
$(0.58)$
\end{tabular} & 1.94 & -64.36 & -0.80 & $\begin{array}{r}-4.35 \\
\end{array}$ & 11.00 & 2.24 & 2.30 & -388.86 & $\begin{array}{r}r-4.4 \\
-7.52 \\
(-3.94)\end{array}$ \\
\hline Percent of Employed & 7.60 & 7.44 & 2146.70 & $\mid 0.07$ & $\begin{array}{c}-10.29 \\
-10.29\end{array}$ & $\mid-1.47$ & $\frac{\mid 0.01}{-1.44}$ & $\begin{array}{l}\mid-0.15) \\
-26.51\end{array}$ & $\begin{array}{l}\mid-0.045 \\
-0.15\end{array}$ & $\begin{array}{r}-2.014 \\
0.14\end{array}$ & $\mid-10.44$ & $\frac{\mid 2.0 .90}{-0.90}$ & $\begin{array}{c}\frac{(2.13)}{-0.90} \\
\end{array}$ & $\mid \begin{array}{c}\mid-2.86) \\
192.35\end{array}$ & $\begin{array}{r}-(-3.94) \\
-0.60\end{array}$ \\
\hline Persons in Manufacturing & $(0.21)$ & $(0.21)$ & $(0.21)$ & $(0.09)$ & $(-1.4)$ & $(-0.81)$ & $(-0.81)$ & $(-0.1)$ & $(-0.37)$ & $(0.27)$ & $(-1.53)$ & $(-2.75)$ & $(-2.77)$ & $(5.12)$ & $(-0.96)$ \\
\hline \begin{tabular}{|l|} 
Percent of Employed \\
Persons in Service
\end{tabular} & $\begin{array}{r}-9.49 \\
(-0.22)\end{array}$ & $\begin{array}{r}-9.29 \\
(-0.23)\end{array}$ & $\begin{array}{r}-2332.85 \\
(-0.21) \\
\end{array}$ & $\begin{array}{r}0.37 \\
(0.43)\end{array}$ & $\begin{array}{r}11.58 \\
(1.5)\end{array}$ & $\begin{array}{r}-0.41 \\
(-0.23)\end{array}$ & $\begin{array}{r}-0.41 \\
(-0.23)\end{array}$ & $\begin{array}{r}-254.88 \\
(-0.94)\end{array}$ & $\begin{array}{r}-0.29 \\
(-0.63)\end{array}$ & $\begin{array}{l}0.82 \\
(15)\end{array}$ & $\begin{array}{r}9.67 \\
(1.29)\end{array}$ & $\begin{array}{r}0.15 \\
(0.37\end{array}$ & $\begin{array}{l}0.16 \\
(0.4)\end{array}$ & $\begin{array}{l}26.20 \\
(0.65)\end{array}$ & $\begin{array}{r}0.75 \\
(0.99)\end{array}$ \\
\hline Unemployment Rate & $\begin{array}{l}-13.01 \\
(-0.46)\end{array}$ & $\begin{array}{l}-12.92 \\
(-0.46)\end{array}$ & $\begin{array}{r}-1447.67 \\
(-0.21)\end{array}$ & $\begin{array}{r}1.79 \\
(1.58)\end{array}$ & $\begin{array}{r}7.82 \\
(0.77)\end{array}$ & $\begin{array}{r}-6.15 \\
(-3.53)\end{array}$ & $\begin{array}{r}-6.20 \\
(-3.64)\end{array}$ & $\begin{array}{r}-105.68 \\
(-0.4)\end{array}$ & $\begin{array}{r}0.26 \\
(0.42)\end{array}$ & $\begin{array}{r}1.52 \\
(2.04)\end{array}$ & $\begin{array}{r}7.88 \\
(0.78)\end{array}$ & $\begin{array}{r}-3.13 \\
(-5.55)\end{array}$ & $\begin{array}{r}-3.15 \\
(-5.63)\end{array}$ & $\begin{array}{r}-184.41 \\
(-3.98)\end{array}$ & $\begin{array}{r}-0.42 \\
(-0.39)\end{array}$ \\
\hline \begin{tabular}{|l|} 
Dummy (Year>1980) \\
\end{tabular} & - & - & 10.21 & 1.1 .00 & $\ldots$ & (5.000 & (1) & $(-0.7)$ & $\ldots$ & $2.07 /$ & $(0.10)$ & $(-0.00)$ & $(-0.00)$ & $(-3.90)$ & \\
\hline Audit Rate & - & -- & -- & - & -- & -- & -- & -- & - & -- & -- & $\begin{array}{r}0.15 \\
(3.48)\end{array}$ & $\begin{array}{r}0.13 \\
(3.19)\end{array}$ & $\begin{array}{l}16.17 \\
(4.44)\end{array}$ & \\
\hline \begin{tabular}{|l|} 
Audit Rate (Revenue \\
Agents)
\end{tabular} & -- & -- & - & - & & \begin{tabular}{r|}
-1.3842 \\
$(-1.19)$ \\
\end{tabular} & $\begin{array}{r}-1.3557 \\
(-1.2)\end{array}$ & $\begin{array}{r}-339.36 \\
(-1.95) \\
\end{array}$ & - & - & - & $(0.40)$ & $(0.10)$ & $(4.44)$ & \\
\hline \begin{tabular}{|l|} 
Audit Rate (Revenue \\
Agents + Tax Auditors)
\end{tabular} & $\begin{array}{r}0.36 \\
(0.28)\end{array}$ & $\begin{array}{r}0.34 \\
(0.27)\end{array}$ & $\begin{array}{r}124.53 \\
(0.27)\end{array}$ & & & & & & & & -- & & -- & $\ldots$ & \\
\hline Audit Rate (Tax Auditors) & - & - & -- & -- & -- & $\begin{array}{r}0.56 \\
(1.54)\end{array}$ & $\begin{array}{r}0.52 \\
(1.48)\end{array}$ & $\begin{array}{r}156.77 \\
(2.9)\end{array}$ & - & -- & - & -. & -- & -- & \\
\hline \begin{tabular}{|l} 
Audit Rate (Service \\
Centers)
\end{tabular} & $\begin{array}{r}0.78 \\
(0.22)\end{array}$ & $\begin{array}{r}0.76 \\
(0.22)\end{array}$ & $\begin{array}{r}254.28 \\
(0.2)\end{array}$ & - & & $\begin{array}{r}-0.08 \\
(-0.56)\end{array}$ & $\begin{array}{r}-0.08 \\
(-0.56)\end{array}$ & $\begin{array}{r}-0.60 \\
(-0.03)\end{array}$ & - & -- & -. & -- & - & -- & \\
\hline Total Sentences & - & 40 & - & -- & $\ldots$ & 1000 & - & -- & - & -- & -- & & -. & - & \\
\hline Tax Sentences & $\ldots$ & $\ldots$ & $\ldots$ & $\ldots$ & $\ldots$ & $\ldots$ & .. & $\ldots$ & $\ldots$ & $\ldots$ & $\ldots$ & $\begin{array}{r}0.00000 \\
(-0.01)\end{array}$ & $\begin{array}{r}-0.00004 \\
(-0.11)\end{array}$ & $\begin{array}{r}0.03478 \\
(0.98)\end{array}$ & $\begin{array}{r}0.00000 \\
(0.12)\end{array}$ \\
\hline $\begin{array}{l}\text { Money Laundering } \\
\text { Sentences }\end{array}$ & .- & .. & .- & .. & .. & .. & ... & ... & & $\ldots$ & $\ldots$ & $\begin{array}{r}-(-0.011) \\
0.00112 \\
(287)\end{array}$ & $\begin{array}{r}(-0.11) \\
0.00111 \\
(286)\end{array}$ & $\begin{array}{r}(0.98) \\
-0.08360 \\
(-247)\end{array}$ & $\begin{array}{r}(0.1) \\
0.00000 \\
(-0.24)\end{array}$ \\
\hline $\begin{array}{l}\text { Percent of Tax Sentences in } \\
\text { Media }\end{array}$ & -. & - & - & -- & - & - & -- & -- & -- & .- & - & $\ldots$ & -- & -- & \\
\hline \begin{tabular}{|l|} 
Percent of Money \\
Laundering Sentences in
\end{tabular} & - & -- & - & - & - & - & .- & -- & & - & & & -- & $\ldots$ & \\
\hline $\begin{array}{l}\text { Percent of Tax Sentences } \\
\text { Resulting in Prison }\end{array}$ & -- & -. & .- & $\ldots$ & & .. & .- & .- & - & .- & & $\ldots$ & $\ldots$ & $\ldots$ & \\
\hline $\begin{array}{l}\text { Percent of Tax Sentences } \\
\text { Resulting in Probation }\end{array}$ & -. & -- & - & -- & -- & - & - & -- & - & - & -- & - & .- & -- & \\
\hline $\begin{array}{l}\text { Percent of Money Laun } \\
\text { Sent Resulting in Prison }\end{array}$ & - & - & - & - & - & - & -- & -- & - & - & .- & $\ldots$ & $\ldots$ & -- & -- \\
\hline $\begin{array}{l}\text { Percent of Money Laun } \\
\text { Sent Resulting in Probation }\end{array}$ & $\ldots$ & .- & .- & .. & .- & - & - & -. & -- & $\ldots$ & -. & $\ldots$ & $\ldots$ & .- & \\
\hline \begin{tabular}{|l|} 
Info returns not W2 filed / \\
tot number of info returns \\
sitar
\end{tabular} & - & -- & - & & & - & - & -- & - & & 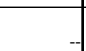 & - & .- & -- & \\
\hline Difarect Examination Time & - & -- & - & $\begin{array}{l}1.182 \\
(7.68)\end{array}$ & $\begin{array}{r}-0.15 \\
(-0.11)\end{array}$ & - & - & -- & $\begin{array}{l}0.189 \\
(2.24)\end{array}$ & $\begin{array}{l}1.015 \\
(9.99)\end{array}$ & $\begin{array}{r}-0.339 \\
(-0.25)\end{array}$ & - & - & -- & $\begin{array}{r}1.028 \\
(5.29)\end{array}$ \\
\hline Budget Per Return & - & - & - & $\begin{array}{r}16.104 \\
(8.09)\end{array}$ & $\begin{array}{r}-8.307 \\
(-0.46)\end{array}$ & - & - & -- & $\begin{array}{l}5.302 \\
(4.84)\end{array}$ & $\begin{array}{r}0.783 \\
(8.19)\end{array}$ & $\begin{array}{l}-8.088 \\
(-0.45)\end{array}$ & $\ldots$ & - & -. & $\begin{array}{l}24.494 \\
(10.16)\end{array}$ \\
\hline \begin{tabular}{|l}
$\begin{array}{l}\text { State Government Ideology } \\
\text { (100 is most liberal) }\end{array}$ \\
\end{tabular} & $\ldots$ & -- & - & - & $\ldots$ & - & -- & -- & $\begin{array}{r}0 \\
0.65)\end{array}$ & $\begin{array}{r}0 \\
(0.29) \\
\end{array}$ & $\begin{array}{r}-0.005 \\
(-1.08) \\
\end{array}$ & & - & $\ldots$ & \\
\hline
\end{tabular}

DGW2: obsno=500 years: $1977-1986$

DGW_IAR2A: obsno=700 years: $1988-2001$

DGW93_12,5: obsno=450 years: $1993-2001$

DGW93_1,2,5: obsno $=450$ years: $1993-200$

DGW_TM1: obsno $=700$ years: $1988-2001$

DGW-TM3: obsno $=700$ years: $1988-2001$ 
TABLE 1 (cont.)

\begin{tabular}{|c|c|c|c|c|c|c|c|c|}
\hline \multirow{2}{*}{ VARIABLE } & \multicolumn{4}{|c|}{ MODEL 7} & \multicolumn{4}{|c|}{ MODEL 8} \\
\hline & ALR & RTR & RCAP & IAR2 & ALR & RTR & RCAP & IAR2 \\
\hline Constant & $\begin{array}{r}0.23 \\
(0.7)\end{array}$ & $\begin{array}{r}0.25 \\
(0.77)\end{array}$ & $\begin{array}{r}204.67 \\
(5.86)\end{array}$ & $\begin{array}{r}1.55 \\
(2.6)\end{array}$ & \begin{tabular}{r|}
1.43 \\
$(3.6)$
\end{tabular} & $\begin{array}{r}1.47 \\
(3.7)\end{array}$ & $\begin{array}{r}147.95 \\
(3.4)\end{array}$ & $\begin{array}{r}-0.001 \\
(0)\end{array}$ \\
\hline Percent of Families on Welfare & $\begin{array}{r}0.00825 \\
(0.98)\end{array}$ & $\begin{array}{r}0.00775 \\
(0.93)\end{array}$ & $\begin{array}{r}-0.48990 \\
(-0.65)\end{array}$ & $\begin{array}{r}0.06330 \\
(4.46)\end{array}$ & $\begin{array}{r}0.00786 \\
(0.8)\end{array}$ & $\begin{array}{r}0.00765 \\
(0.78)\end{array}$ & $\begin{array}{r}-1.56726 \\
(-1.58)\end{array}$ & $\begin{array}{r}0.09710 \\
(8.3)\end{array}$ \\
\hline State Tax Rate & $\begin{array}{r}-0.0055 \\
(-0.95)\end{array}$ & $\begin{array}{r}-0.0054 \\
(-0.93)\end{array}$ & $\begin{array}{r}-2.4248 \\
(-3.16)\end{array}$ & $\begin{array}{r}-0.0120 \\
(-1.16)\end{array}$ & $\begin{array}{r}-0.0253 \\
(-3.09)\end{array}$ & $\begin{array}{r}-0.0254 \\
(-3.1)\end{array}$ & $\begin{array}{r}-0.2042 \\
(-0.17)\end{array}$ & $\begin{array}{r}-0.0170 \\
(-1.38)\end{array}$ \\
\hline Personal Income Per Capita & $\begin{array}{r}0.329 \\
(18.99)\end{array}$ & $\begin{array}{l}0.330 \\
(19.1)\end{array}$ & $\begin{array}{r}12.019 \\
(6.38)\end{array}$ & $\begin{array}{l}-0.119 \\
(-4.09)\end{array}$ & $\begin{array}{r}0.311 \\
(17.32)\end{array}$ & $\begin{array}{r}0.312 \\
(17.41)\end{array}$ & $\begin{array}{r}16.453 \\
(8.32)\end{array}$ & $\begin{array}{r}-0.080 \\
(-3.1)\end{array}$ \\
\hline Family Size & $\begin{array}{l}-1.527 \\
(-1.57)\end{array}$ & $\begin{array}{l}-1.604 \\
(-1.66)\end{array}$ & $\begin{array}{r}510.856 \\
(5.1)\end{array}$ & $\begin{array}{r}1.419 \\
(0.8)\end{array}$ & $\begin{array}{r}-0.954 \\
(-1)\end{array}$ & $\begin{array}{r}-1.052 \\
(-1.1)\end{array}$ & $\begin{array}{r}407.125 \\
(4.05)\end{array}$ & $\begin{array}{l}0.279 \\
(0.19)\end{array}$ \\
\hline Farms Per Household & $\begin{array}{r}-0.24 \\
(-0.13)\end{array}$ & $\begin{array}{r}-0.09 \\
(-0.05)\end{array}$ & $\begin{array}{r}-134.29 \\
(-0.44)\end{array}$ & $\begin{array}{r}4.53 \\
(1.34)\end{array}$ & $\begin{array}{r}-2.92 \\
(-1.22)\end{array}$ & $\begin{array}{r}-2.71 \\
(-1.14)\end{array}$ & $\begin{array}{r}-23.80 \\
(-0.07)\end{array}$ & $\begin{array}{r}7.16 \\
(2.01) \\
\end{array}$ \\
\hline $\begin{array}{l}\text { Percent of Adults with High School } \\
\text { Diploma }\end{array}$ & $\begin{array}{r}-0.72 \\
(-5.12)\end{array}$ & $\begin{array}{r}-0.74 \\
(-5.22)\end{array}$ & $\begin{array}{l}31.86 \\
(2.55)\end{array}$ & $\begin{array}{r}-1.06 \\
(-4.01)\end{array}$ & $\begin{array}{r}-1.71 \\
(-6.91)\end{array}$ & $\begin{array}{r}-1.73 \\
(-7.00)\end{array}$ & $\begin{array}{r}89.30 \\
(3.54)\end{array}$ & $\begin{array}{r}0.29 \\
(0.77) \\
\end{array}$ \\
\hline Percent of Pop Over 65 & $\begin{array}{r}1.90 \\
(1.89)\end{array}$ & $\begin{array}{r}1.95 \\
(1.94) \\
\end{array}$ & $\begin{array}{r}-401.06 \\
(-2.98) \\
\end{array}$ & $\begin{array}{r}-7.04 \\
(-4.04) \\
\end{array}$ & $\begin{array}{r}1.28 \\
(1.06) \\
\end{array}$ & $\begin{array}{r}1.32 \\
(1.10) \\
\end{array}$ & $\begin{array}{r}-321.31 \\
(-2.04) \\
\end{array}$ & $\begin{array}{l}-4.27 \\
(-2.4) \\
\end{array}$ \\
\hline $\begin{array}{l}\text { Percent of Employed Persons in } \\
\text { Manufacturing }\end{array}$ & $\begin{array}{r}-0.78 \\
(-2.55)\end{array}$ & $\begin{array}{r}-0.78 \\
(-2.54)\end{array}$ & $\begin{array}{r}180.60 \\
(4.8) \\
\end{array}$ & $\begin{array}{l}-0.51 \\
(-0.9)\end{array}$ & $\begin{array}{r}-0.33 \\
(-0.82)\end{array}$ & $\begin{array}{r}-0.33 \\
(-0.82)\end{array}$ & $\begin{array}{r}144.80 \\
(2.9) \\
\end{array}$ & $\begin{array}{r}-0.08 \\
(-0.14)\end{array}$ \\
\hline $\begin{array}{l}\text { Percent of Employed Persons in } \\
\text { Service }\end{array}$ & $\begin{array}{r}0.13 \\
(0.33)\end{array}$ & $\begin{array}{r}0.15 \\
(0.38)\end{array}$ & $\begin{array}{r}-0.42 \\
(-0.01) \\
\end{array}$ & $\begin{array}{r}1.30 \\
(1.8)\end{array}$ & $\begin{array}{r}-0.32 \\
(-0.68)\end{array}$ & $\begin{array}{r}-0.30 \\
(-0.64) \\
\end{array}$ & $\begin{array}{r}-41.06 \\
(-0.8)\end{array}$ & $\begin{array}{r}0.91 \\
(1.29)\end{array}$ \\
\hline Unemployment Rate & $\begin{array}{r}-3.13 \\
(-5.55)\end{array}$ & $\begin{array}{r}-3.15 \\
(-5.62)\end{array}$ & $\begin{array}{r}-193.25 \\
(-4.14) \\
\end{array}$ & $\begin{array}{r}0.08 \\
(0.08)\end{array}$ & $\begin{array}{r}-6.53 \\
(-10.46)\end{array}$ & $\begin{array}{r}-6.55 \\
(-10.53)\end{array}$ & $\begin{array}{l}-89.36 \\
(-1.46)\end{array}$ & $\begin{array}{r}1.31 \\
(1.36) \\
\end{array}$ \\
\hline Dummy (Year>1980) & -- & -- & - & -- & -- & -- & -- & $\ldots$ \\
\hline Audit Rate & $\begin{array}{r}0.14 \\
(3.28) \\
\end{array}$ & $\begin{array}{r}0.13 \\
(2.98) \\
\end{array}$ & $\begin{array}{r}17.33 \\
(4.75) \\
\end{array}$ & - & $\begin{array}{r}0.10 \\
(2.06) \\
\end{array}$ & $\begin{array}{r}0.09 \\
(1.71) \\
\end{array}$ & $\begin{array}{c}31.07 \\
(6.31)\end{array}$ & - \\
\hline Audit Rate (Revenue Agents) & -- & -- & -- & -- & -- & -- & -- & $\ldots$ \\
\hline $\begin{array}{l}\text { Audit Rate (Revenue Agents+Tax } \\
\text { Auditors) }\end{array}$ & -- & -- & -- & -- & -- & -- & -- & - \\
\hline Audit Rate (Tax Auditors) & -- & -- & -- & -- & -- & -- & -- & - \\
\hline Audit Rate (Service Centers) & -- & -- & -- & -- & -- & - & -- & - \\
\hline Total Sentences & -- & -- & -- & -- & -- & - & -- & $\ldots$ \\
\hline Tax Sentences & $\begin{array}{r}-0.00010 \\
(-0.27) \\
\end{array}$ & $\begin{array}{r}-0.00013 \\
(-0.37) \\
\end{array}$ & $\begin{array}{r}0.03410 \\
(0.95) \\
\end{array}$ & $\begin{array}{r}0.00000 \\
(0.27) \\
\end{array}$ & $\begin{array}{r}0.00048 \\
(1.17) \\
\end{array}$ & $\begin{array}{r}0.00047 \\
(1.15) \\
\end{array}$ & $\begin{array}{r}0.01078 \\
(0.26) \\
\end{array}$ & $\begin{array}{l}-0.001 \\
(-1.49)\end{array}$ \\
\hline Money Laundering Sentences & $\begin{array}{r}0.00121 \\
(3.15) \\
\end{array}$ & $\begin{array}{r}0.00120 \\
(3.14) \\
\end{array}$ & $\begin{array}{r}-0.08378 \\
(-2.46) \\
\end{array}$ & $\begin{array}{r}0.00000 \\
(-0.37) \\
\end{array}$ & $\begin{array}{r}0.00000 \\
(0.00) \\
\end{array}$ & $\begin{array}{r}-0.00003 \\
(-0.07) \\
\end{array}$ & $\begin{array}{r}-0.04440 \\
(-0.92) \\
\end{array}$ & $\begin{array}{l}0.001 \\
(1.25) \\
\end{array}$ \\
\hline Percent of Tax Sentences in Media & -- & -- & -- & -- & $\begin{array}{l}-0.044 \\
(-2.22)\end{array}$ & $\begin{array}{l}-0.044 \\
(-2.23) \\
\end{array}$ & $\begin{array}{l}4.248 \\
(2.25) \\
\end{array}$ & $\begin{array}{l}0.026 \\
(0.87) \\
\end{array}$ \\
\hline $\begin{array}{l}\text { Percent of Money Laundering } \\
\text { Sentences in Media }\end{array}$ & -- & -- & -- & -- & $\begin{array}{r}0.025 \\
(1.54)\end{array}$ & $\begin{array}{l}0.024 \\
(1.49)\end{array}$ & $\begin{array}{r}3.933 \\
(2.51)\end{array}$ & $\begin{array}{l}-0.024 \\
(-0.95)\end{array}$ \\
\hline $\begin{array}{l}\text { Percent of Tax Sentences } \\
\text { Resulting in Prison }\end{array}$ & $\begin{array}{l}-0.023 \\
(-0.93)\end{array}$ & $\begin{array}{l}-0.022 \\
(-0.88)\end{array}$ & $\begin{array}{r}3.354 \\
(1.67)\end{array}$ & $\begin{array}{l}-0.017 \\
(-0.38)\end{array}$ & -- & - & -- & $\ldots$ \\
\hline \begin{tabular}{|l} 
Percent of Tax Sentences \\
Resulting in Probation
\end{tabular} & $\begin{array}{r}0.00046 \\
(0.02)\end{array}$ & $\begin{array}{r}-0.00059 \\
(-0.02)\end{array}$ & $\begin{array}{r}-1.53718 \\
(-0.65)\end{array}$ & $\begin{array}{r}0.082 \\
(1.53)\end{array}$ & - & - & -- & $\ldots$ \\
\hline $\begin{array}{l}\text { Percent of Money Laun Sent } \\
\text { Resulting in Prison }\end{array}$ & $\begin{array}{l}-0.038 \\
(-1.89)\end{array}$ & $\begin{array}{l}-0.037 \\
(-1.86)\end{array}$ & $\begin{array}{l}0.200 \\
(0.12)\end{array}$ & $\begin{array}{r}-0.150 \\
(-3.95)\end{array}$ & -- & -- & -- & $\ldots$ \\
\hline $\begin{array}{l}\text { Percent of Money Laun Sent } \\
\text { Resulting in Probation }\end{array}$ & $\begin{array}{r}0.049 \\
(2.31)\end{array}$ & $\begin{array}{r}0.047 \\
(2.2)\end{array}$ & $\begin{array}{l}3.896 \\
(2.25)\end{array}$ & $\begin{array}{l}-0.012 \\
(-0.31)\end{array}$ & -- & -- & -- & $\ldots$ \\
\hline $\begin{array}{l}\text { Info returns not W2 filed / tot } \\
\text { number of info returns filed }\end{array}$ & -- & -- & - & -- & -- & - & -- & - \\
\hline Direct Examination Time & -- & -- & - & $\begin{array}{r}1.142 \\
(5.95) \\
\end{array}$ & -- & -- & -- & $\begin{array}{l}1.238 \\
(8.15)\end{array}$ \\
\hline Budget Per Return & -- & -- & -- & $\begin{array}{r}23.862 \\
(9.98) \\
\end{array}$ & -- & -- & -- & $\begin{array}{r}15.579 \\
(8.5) \\
\end{array}$ \\
\hline $\begin{array}{l}\text { State Government Ideology (100 is } \\
\text { most liberal) }\end{array}$ & -- & -- & - & -- & -- & - & -- & - \\
\hline
\end{tabular}

DGW2: obsno $=500$ years: $1977-1986$

DGW_IAR2A: obsno=700 years: $1988-2001$

DGW93 12,5: obsno=450 years: 1993-2001

DGW93 1,2,5: obsno=450 years: $1993-2001$

DGW TM1: obsno $=700$ years: $1988-2001$

DGW_TM3: obsno $=700$ years: $1988-2001$

DGW_MD1: obsno=500 years: $1992-2001$ 
TABLE 2

\begin{tabular}{|c|c|c|c|c|c|c|c|c|c|c|c|c|c|c|c|c|}
\hline \multirow{2}{*}{ VARIABLE } & \multicolumn{4}{|c|}{ MODEL 9} & \multicolumn{4}{|c|}{ MODEL 10} & \multicolumn{4}{|c|}{ MODEL 11} & \multicolumn{4}{|c|}{ MODEL 12} \\
\hline & ALR & RTR & RCAP & IAR2 & ALR & RTR & RCAP & IAR2 & ALR & RTR & RCAP & IAR2 & ALR & RTR & RCAP & IAR2 \\
\hline Constant & 0.19 & 0.22 & 0.19 & 1.91 & 0.14 & 0.17 & 0.19 & 1.87 & 0.12 & 0.15 & 0.19 & 1.61 & 0.21 & 0.23 & 0.20 & 1.55 \\
\hline & $(0.57)$ & $(0.66)$ & (5.42) & (3.24) & $(0.43)$ & $(0.52)$ & (5.33) & (3.06) & $(0.38)$ & $(0.46)$ & (5.44) & (2.85) & (0.64) & (0.7) & (5.75) & (2.61) \\
\hline Percent of Families on Welfare & $\begin{array}{r}0.00559 \\
(0.65)\end{array}$ & $\begin{array}{r}0.00521 \\
(0.61)\end{array}$ & $\begin{aligned}-0.00056 \\
(-0.73)\end{aligned}$ & $\begin{array}{r}0.06501 \\
(4.71)\end{array}$ & $\begin{array}{r}0.00926 \\
(1.12)\end{array}$ & $\begin{aligned} 0.00866 \\
(1.05)\end{aligned}$ & $\begin{array}{r}-0.00027 \\
(-0.37)\end{array}$ & $\begin{array}{r}0.06129 \\
(4.29)\end{array}$ & $\begin{array}{r}0.00352 \\
(0.41)\end{array}$ & $\begin{aligned} 0.00316 \\
(0.37)\end{aligned}$ & $\begin{array}{r}-0.00058 \\
(-0.73)\end{array}$ & $\begin{array}{r}0.06608 \\
(4.93)\end{array}$ & $\begin{array}{r}.00732 \\
(0.88)\end{array}$ & $\begin{aligned} 0.00680 \\
(0.82)\end{aligned}$ & $\begin{array}{r}-0.00047 \\
(-0.62)\end{array}$ & $\begin{array}{r}0.06329 \\
(4.48)\end{array}$ \\
\hline Family Size & -1.7768 & -1.8732 & 0.5175 & 1.0760 & \begin{tabular}{|c|}
-1.7869 \\
\end{tabular} & \begin{tabular}{|c|c|c|}
-1.874 \\
\end{tabular} & 0.5684 & 1.4303 & -1.7491 & -1.8335 & 0.5490 & 1.5028 & $\mid-1.7046$ & -1.7863 & 0.5508 & 1.4841 \\
\hline & $(-1.78)$ & $(-1.88)$ & $(5.15)$ & $(0.61)$ & $(-1.84)$ & $(-1.93)$ & $(5.72)$ & $(0.8)$ & $(-1.83)$ & $(-1.92)$ & $(5.45)$ & $(0.91)$ & $(-1.78)$ & $(-1.87)$ & (5.57) & $(0.85)$ \\
\hline Farms Per Household & -0.369 & -0.172 & -0.190 & 5.361 & 0.511 & 0.679 & -0.213 & 4.183 & -0.341 & -0.143 & -0.268 & 5.642 & 0.226 & 0.399 & -0.218 & 4.353 \\
\hline & $(-0.19)$ & $(-0.09)$ & $(-0.63)$ & (1.53) & $(0.28)$ & $(0.37)$ & $(-0.71)$ & (1.22) & $(-0.19)$ & $(-0.08)$ & $(-0.92)$ & (1.8) & (0.13) & $(0.22)$ & $(-0.73)$ & (1.32) \\
\hline Percent of Adults with High School & -0.711 & -0.726 & 0.038 & -1.160 & -0.602 & -0.615 & 0.029 & -1.124 & -0.589 & -0.602 & 0.030 & -1.076 & -0.633 & -0.643 & 0.026 & -1.092 \\
\hline Diploma & $(-5.02)$ & $(-5.15)$ & (3) & $(-4.57)$ & $(-4.3)$ & $(-4.42)$ & $(2.3)$ & $(-4.25)$ & $(-4.24)$ & $(-4.35)$ & (2.37) & $(-4.33)$ & $(-4.61)$ & $(-4.7)$ & $(2.08)$ & $(-4.27)$ \\
\hline Unemployment Rate & -3.10 & -3.13 & -0.19 & -0.10 & -3.06 & -3.08 & -0.19 & -0.03 & -3.01 & -3.03 & -0.20 & 0.35 & -3.03 & -3.05 & -0.20 & 0.07 \\
\hline & $(-5.49)$ & $(-5.57)$ & $(-3.97)$ & $(-0.09)$ & $(-5.4)$ & $(-5.46)$ & $(-4.03)$ & $(-0.03)$ & $(-5.3)$ & $(-5.36)$ & $(-4.1)$ & $(0.35)$ & $(-5.37)$ & $(-5.44)$ & $(-4.25)$ & $(0.07)$ \\
\hline Personal Income Per Capita & 0.33 & 0.34 & 0.01 & -0.11 & 0.32 & 0.33 & 0.01 & -0.12 & 0.32 & 0.32 & 0.01 & -0.11 & 0.32 & 0.33 & 0.01 & -0.12 \\
\hline & (18.57) & (18.68) & (6.4) & $(-3.86)$ & (18.53) & (18.63) & $(6.33)$ & $(-4.13)$ & (18.93) & (19.02) & (6.52) & $(-3.82)$ & (18.95) & (19.05) & $(6.39)$ & $(-4.09)$ \\
\hline Percent of Employed Persons in & -0.75 & -0.76 & 0.19 & -0.91 & -0.75 & -0.75 & 0.19 & -0.64 & -0.57 & -0.58 & 0.19 & -0.92 & -0.75 & -0.75 & 0.18 & -0.53 \\
\hline & $(-2.3)$ & $(-2.33)$ & (5.12) & $(-1.57)$ & $(-2.42)$ & $(-2.43)$ & $(5.09)$ & $(-1.1)$ & $(-1.88)$ & $(-1.9)$ & $(5.02)$ & $(-1.72)$ & $(-2.47)$ & $(-2.47)$ & (4.87) & $(-0.94)$ \\
\hline Percent of Employed Persons in Service & 0.13 & 0.14 & 0.02 & 0.70 & 0.37 & 0.39 & 0.00 & 0.98 & 0.34 & 0.35 & -0.01 & 0.96 & 0.29 & 0.31 & -0.02 & 1.24 \\
\hline & $(0.32)$ & $(0.35)$ & $(0.54)$ & $(0.98)$ & $(0.94)$ & $(0.99)$ & $(-0.03)$ & $(1.34)$ & $(0.86)$ & $(0.91)$ & $(-0.2)$ & (1.42) & $(0.74)$ & (0.8) & $(-0.47)$ & (1.75) \\
\hline Percent of Pop Over 65 & 2.40 & 2.45 & -0.37 & -7.35 & 1.88 & 1.93 & -0.39 & -7.03 & 1.98 & 2.02 & -0.37 & -6.79 & 1.79 & 1.84 & -0.40 & -6.95 \\
\hline & (2.23) & (2.29) & $(-2.71)$ & $(-4.12)$ & $(1.85)$ & (1.9) & $(-2.88)$ & $(-3.96)$ & (2) & $(2.04)$ & $(-2.75)$ & $(-4.17)$ & (1.81) & (1.85) & $(-2.98)$ & $(-4.05)$ \\
\hline State Tax Rate & -0.006 & -0.005 & -0.003 & -0.006 & -0.0054 & -0.0053 & -0.0023 & -0.0133 & -0.008 & -0.008 & -0.002 & -0.008 & -0.006 & -0.006 & -0.002 & -0.012 \\
\hline & $(-0.93)$ & $(-0.89)$ & $(-3.39)$ & $(-0.59)$ & $(-0.93)$ & $(-0.91)$ & $(-2.94)$ & $(-1.24)$ & $(-1.37)$ & $(-1.33)$ & $(-3.24)$ & $(-0.86)$ & $(-1.05)$ & $(-1.04)$ & $(-3.05)$ & $(-1.17)$ \\
\hline Total Sentences & & & & & & & & & & & & & 0.00046 & 0.00045 & -0.00003 & 0.00000 \\
\hline & & & & & & & & & & & & & (2.32) & (2.24) & $(-1.27)$ & $(0.01)$ \\
\hline $\begin{array}{l}\text { Total Sentences Either Tax or Money } \\
\text { Laundering }\end{array}$ & & & & & $\begin{array}{r}0.0005 \\
(2.23) \\
\end{array}$ & $\begin{array}{r}0.0005 \\
(2.14) \\
\end{array}$ & $\begin{array}{l}0.0000 \\
(-1.08) \\
\end{array}$ & $\begin{array}{r}.0001 \\
(0.17) \\
\end{array}$ & $\begin{array}{r}0.00055 \\
(2.29) \\
\end{array}$ & $\begin{array}{r}0.00053 \\
(2.19) \\
\end{array}$ & $\begin{array}{r}-0.00003 \\
(-1.23) \\
\end{array}$ & $\begin{array}{r}0.00006 \\
(0.15) \\
\end{array}$ & & & & \\
\hline Tax Sentences & $\begin{array}{r}0.00001 \\
(0.02)\end{array}$ & $\begin{array}{r}-0.00003 \\
(-0.08)\end{array}$ & $\begin{array}{r}0.00003 \\
(0.84)\end{array}$ & $\begin{array}{r}0.00012 \\
(0.19)\end{array}$ & & & & & & & & & & & & \\
\hline Money Laun Sentences & $\begin{array}{r}0.00111 \\
(2.84)\end{array}$ & $\begin{array}{r}0.00110 \\
(2.83)\end{array}$ & $\begin{array}{r}-0.00008 \\
(-2.47)\end{array}$ & $\begin{array}{r}-0.00024 \\
(-0.34)\end{array}$ & & & & & & & & & & & & \\
\hline Tax Sentences / Total Sentences & & & & & $\begin{array}{r}0.03242 \\
(0.89) \\
\end{array}$ & $\begin{array}{r}.03075 \\
(0.85) \\
\end{array}$ & $\begin{array}{r}-0.00004 \\
(-0.01) \\
\end{array}$ & $\begin{array}{r}-0.14580 \\
(-2.17) \\
\end{array}$ & $\begin{array}{r}0.03836 \\
(1.05) \\
\end{array}$ & $\begin{array}{r}0.03642 \\
(1) \\
\end{array}$ & $\begin{array}{r}0.00047 \\
(0.15) \\
\end{array}$ & $\begin{array}{r}-0.14956 \\
(-2.35) \\
\end{array}$ & & & & \\
\hline Money Laun Sentences / Total Sentences & & & & & $\begin{array}{ll}1.14 \mathrm{E}-02 \\
\end{array}$ & $\begin{array}{r}9.47 \mathrm{E}-03 \\
(0.23)\end{array}$ & \begin{tabular}{rl|}
$1.43 E-03$ \\
\end{tabular} & $-2.41 \mathrm{E}-01$ & $\begin{array}{ll}2.06 \mathrm{E}-02 \\
\end{array}$ & \begin{tabular}{rl|}
$1.80 \mathrm{E}-02$ \\
\end{tabular} & \begin{tabular}{rl|}
$2.58 \mathrm{E}-03$ \\
\end{tabular} & $-2.64 E-01$ & & & & \\
\hline $\begin{array}{l}\text { Tax Sentences Neither Pris nor Prob/ } \\
\text { Total Tax Sentences }\end{array}$ & $\begin{array}{r}3.33 \mathrm{E}-02 \\
(0.37)\end{array}$ & $\begin{array}{r}2.76 \mathrm{E}-02 \\
(0.31)\end{array}$ & $\begin{array}{r}9.69 \mathrm{E}-03 \\
(1.31)\end{array}$ & $\begin{array}{r}-4.31 \mathrm{E}-01 \\
(-2.71) \\
\end{array}$ & & & & & $\begin{array}{l}0.45 \\
0.006 \\
(0.06)\end{array}$ & $\begin{array}{r}-0.001 \\
-(-0.01) \\
\end{array}$ & $\begin{array}{l}0.012 \\
(1.59)\end{array}$ & $\begin{array}{r}-0.468 \\
-0.468 \\
(-2.95)\end{array}$ & & & & \\
\hline $\begin{array}{l}\text { Money Laun Sentences Neither Pris nor } \\
\text { Prob / Total Money Laun Sentences }\end{array}$ & $\begin{array}{r}-3.55 \mathrm{E}-01 \\
(-4.48)\end{array}$ & $\begin{array}{r}-3.39 E-01 \\
(-4.3)\end{array}$ & $\begin{array}{r}-1.82 \mathrm{E}-02 \\
(-2.76)\end{array}$ & $\begin{array}{r}9.41 \mathrm{E}-01 \\
(8.611\end{array}$ & & & & & $\begin{array}{r}-3.55 \mathrm{E}-01 \\
(-4.44)\end{array}$ & $\begin{array}{r}-3.38 E-01 \\
(-4.26)\end{array}$ & $\begin{array}{r}-1.85 \mathrm{E}-02 \\
(-2.75)\end{array}$ & $\begin{array}{r}9.48 \mathrm{E}-01 \\
(8.72)\end{array}$ & & & & \\
\hline $\begin{array}{l}\text { Money Laun Pris Sentences / Money Laun } \\
\text { Sentences }\end{array}$ & & & & & & & & & & & & & $\begin{array}{r}0.04609 \\
(2.16)\end{array}$ & $\begin{array}{r}0.04346 \\
(2.05)\end{array}$ & $\begin{array}{r}0.00418 \\
(2.41)\end{array}$ & $\begin{array}{r}-0.15003 \\
(-3.94)\end{array}$ \\
\hline Tax Pris Sentences / Tax Sentences & & & & & & & & & & & & & $\begin{array}{r}-1.97 E-02 \\
(-0.79) \\
\end{array}$ & $\begin{array}{r}-1.82 \mathrm{E}-02 \\
(-0.73) \\
\end{array}$ & $\begin{array}{r}.11 \mathrm{E}-03 \\
(1.54) \\
\end{array}$ & $\begin{array}{r}-1.94 \mathrm{E}-02 \\
(-0.42) \\
\end{array}$ \\
\hline $\begin{array}{l}\text { Money Laun Prob Sentences / Money } \\
\text { Laun Sentences }\end{array}$ & & & & & & & & & & & & & $\begin{array}{r}-3.48 \mathrm{E}-02 \\
(-1.74) \\
\end{array}$ & \begin{tabular}{|l|l|}
$-3.40 E-02$ \\
$(-1.71)$
\end{tabular} & $\begin{array}{r}1.87 E-05 \\
(0.01)\end{array}$ & $\begin{array}{l}-1.25 \mathrm{E}-02 \\
(-0.34) \\
\end{array}$ \\
\hline Tax Prob Sentences / Tax Sentences & & & & & & & & & & & & & 0.003 & $\begin{aligned}(-1.71) \\
0.002\end{aligned}$ & -0.002 & 0.081 \\
\hline & & & & & & & & & & & & & $(0.1)$ & $(0.07)$ & $(-0.68)$ & (1.52) \\
\hline Audit Rate & 0.18 & 0.17 & 0.02 & & $1.35 \mathrm{E}-01$ & $1.22 \mathrm{E}-01$ & $1.66 \mathrm{E}-02$ & & 0.17 & 0.15 & 0.02 & & 0.13 & 0.12 & 0.02 & \\
\hline & (3.93) & (3.64) & $(4.69)$ & & (3.19) & (2.89) & (4.5) & & (3.66) & (3.35) & $(4.73)$ & & (3.15) & $(2.84)$ & (4.77) & \\
\hline Budget Per Return & & & & $\begin{array}{l}22.06 \\
(9.49)\end{array}$ & & & & $\begin{array}{r}24.51 \\
(10.22)\end{array}$ & & & & $\begin{array}{l}22.11 \\
(9.57)\end{array}$ & & & & $\begin{array}{r}23.95 \\
(10.04)\end{array}$ \\
\hline Direct Examination Time & & & & $\begin{array}{r}1.05145 \\
(5.711 \\
\end{array}$ & & & & $\begin{array}{r}1.05 \\
\end{array}$ & & & & $\begin{array}{r}1.08 \\
589\end{array}$ & & & & $\begin{array}{r}1.14 \\
5.97\end{array}$ \\
\hline
\end{tabular}

Number of observations: 700

Years of analysis: 1988-200 
TABLE 3

\begin{tabular}{|c|c|c|c|c|c|c|c|c|c|c|c|c|}
\hline \multirow{3}{*}{ LOG FILE } & \multirow{3}{*}{$\begin{array}{c}\text { VARIABLE } \\
\text { SUBSTITUTION }\end{array}$} & \multirow{3}{*}{$\begin{array}{l}\text { SIGNIFICANT } \\
\text { VARIBLES }\end{array}$} & \multicolumn{3}{|c|}{ ESTIMATED ASSESSED TAX COLLECTIONS } & \multicolumn{3}{|c|}{ ESTIMATED REPORTED TAX COLLECTIONS } & \multirow{3}{*}{$\begin{array}{l}\text { Actual Reported } \\
\text { Collections } \\
\text { (\$millions) } \\
\text { (G) }\end{array}$} & \multirow{3}{*}{$\begin{array}{l}\% \text { of Estimated } \\
\text { Reported } \\
\text { Difference and } \\
\text { Actual Reported } \\
\text { Tax Revenue } \\
\text { (F/G) } \\
\text { (H) }\end{array}$} & \multirow{3}{*}{$\begin{array}{l}\text { \% of Estimated } \\
\text { Reported } \\
\text { Difference and } \\
\text { Estimated } \\
\text { Reported Tax } \\
\text { Revenue } \\
\text { (F/E) } \\
\text { (I) }\end{array}$} & \multirow{3}{*}{$\begin{array}{l}\text { \% Change in } \\
\text { Estimated } \\
\text { Assessed and } \\
\text { Reported Tax } \\
\text { Revenue } \\
\text { (C-F)/F } \\
\text { (J) }\end{array}$} \\
\hline & & & $\begin{array}{c}\text { Amount } \\
\text { (Smillions) }\end{array}$ & $\begin{array}{l}\text { Original Amount } \\
\text { (Smillions) }\end{array}$ & $\begin{array}{l}\text { Difference } \\
\text { (A-B) }\end{array}$ & $\begin{array}{c}\text { Amount } \\
\text { (\$millions) }\end{array}$ & $\begin{array}{c}\text { Amount } \\
\text { (\$millions) }\end{array}$ & $\begin{array}{l}\text { Difference } \\
\text { (D-E) }\end{array}$ & & & & \\
\hline & & & (A) & (B) & (C) & (D) & (E) & (F) & & & & \\
\hline \multirow{8}{*}{ MODEL 9} & $\operatorname{IAR2} 2->2 * \operatorname{IAR2}$ & IAR2 & $\$ 965,033$ & $\$ 945,424$ & $\$ 19,609$ & $\$ 962,652$ & $\$ 944,152$ & $\$ 18,500$ & $\$ 882,128$ & $2.1 \%$ & $2.0 \%$ & $6.0 \%$ \\
\hline & $\mathrm{T}->>2 * \mathrm{~T}$ & & $\$ 948,345$ & $\$ 945,424$ & $\$ 2,921$ & $\$ 946,322$ & $\$ 944,152$ & $\$ 2,170$ & $\$ 882,128$ & $0.2 \%$ & $0.2 \%$ & $34.6 \%$ \\
\hline & $M-\rightarrow 2 \times M$ & M & $\$ 960,995$ & $\$ 945,424$ & $\$ 15,571$ & $\$ 959,499$ & \begin{tabular}{l|l}
$\$ 944,152$ \\
\end{tabular} & $\$ 15,347$ & $\$ 882,128$ & $1.7 \%$ & $1.6 \%$ & $1.5 \%$ \\
\hline & $\mid \begin{array}{ll}T \rightarrow-2 \\
M->2\end{array}: \frac{T}{M}$ & M & $\$ 964,029$ & $\$ 945,424$ & $\$ 18,605$ & $\$ 961,792$ & $\$ 944,152$ & $\$ 17,640$ & $\$ 882,128$ & $2.0 \%$ & $1.9 \%$ & $5.5 \%$ \\
\hline & 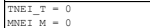 & MNEI_M & $\$ 946,515$ & $\$ 945,424$ & $\$ 1,091$ & $\$ 945,208$ & $\$ 944,152$ & $\$ 1,056$ & $\$ 882,128$ & $0.1 \%$ & $0.1 \%$ & $3.3 \%$ \\
\hline & TNEI_L -0 & & $\$ 945,286$ & $\$ 945,424$ & $-\$ 138$ & $\$ 944,024$ & $\$ 944,152$ & $-\$ 128$ & $\$ 882,128$ & $0.0 \%$ & $0.0 \%$ & $7.8 \%$ \\
\hline & MNEE_L $M-0$ & MNEI_M & $\$ 946,654$ & $\$ 945,424$ & $\$ 1,230$ & $\$ 945,336$ & $\$ 944,152$ & $\$ 1,184$ & $\$ 882,128$ & $0.1 \%$ & $0.1 \%$ & $3.9 \%$ \\
\hline & 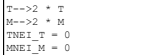 & M, MNEI_M & $\$ 965,120$ & $\$ 945,424$ & $\$ 19,696$ & $\$ 962,848$ & $\$ 944,152$ & $\$ 18,696$ & $\$ 882,128$ & $2.1 \%$ & $2.0 \%$ & $5.3 \%$ \\
\hline \multirow{5}{*}{ MODEL 10} & $\operatorname{IAR2} 2 \ldots 2 \cdot \operatorname{TAR} 2$ & IAR2 & $\$ 958,328$ & $\$ 942,871$ & $\$ 15,457$ & $\$ 955,887$ & $\$ 941,451$ & $\$ 14,436$ & $\$ 882,128$ & $1.6 \%$ & $1.5 \%$ & $7.1 \%$ \\
\hline & TOTTM-> $2+$ ToTTM & TOTTM & $\$ 960,273$ & $\$ 942,871$ & $\$ 17,402$ & $\$ 957,872$ & $\$ 941,451$ & $\$ 16,421$ & $\$ 882,128$ & $1.9 \%$ & $1.7 \%$ & $6.0 \%$ \\
\hline & 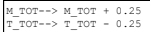 & & $\$ 940,981$ & $\$ 942,871$ & $-\$ 1,890$ & $\$ 939,521$ & $\$ 941,451$ & $-\$ 1,930$ & $\$ 882,128$ & $-0.2 \%$ & $-0.2 \%$ & $-2.1 \%$ \\
\hline & $\begin{array}{l}\text { T-TOT-> T_TOT }+0.25 \\
\text { M_TOT->> M_TOT }=0.25\end{array}$ & & $\$ 944,774$ & $\$ 942,871$ & $\$ 1,903$ & $\$ 943,387$ & $\$ 941,451$ & $\$ 1,936$ & $\$ 882,128$ & $0.2 \%$ & $0.2 \%$ & $-1.7 \%$ \\
\hline & 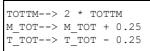 & TOTTM & $\$ 958,413$ & $\$ 942,871$ & $\$ 15,542$ & $\$ 955,972$ & $\$ 941,451$ & $\$ 14,521$ & $\$ 882,128$ & $1.6 \%$ & $1.5 \%$ & $7.0 \%$ \\
\hline \multirow{9}{*}{ MODEL 11} & IAR2 $\Rightarrow>2 \cdot$ IAR2 & IAR2 & $\$ 959,064$ & $\begin{array}{l}940,358 \\
\end{array}$ & $\$ 18,706$ & \begin{tabular}{l|l|}
$\$ 956,602$ \\
\end{tabular} & \begin{tabular}{|l|}
$\$ 939,031$ \\
\end{tabular} & $\$ 17,571$ & \begin{tabular}{|l|l|}
$\$ 882,128$ \\
\end{tabular} & $2.0 \%$ & $1.9 \%$ & $6.5 \%$ \\
\hline & TOTTMM-> $2 \cdot$ TOTTM & TOTTM & $\$ 957,038$ & $\$ 940,358$ & $\$ 16,680$ & $\$ 954,729$ & $\$ 939,031$ & $\$ 15,698$ & $\begin{array}{l}\$ 882,128 \\
\end{array}$ & $1.8 \%$ & $1.7 \%$ & $6.3 \%$ \\
\hline & 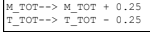 & & $\$ 939,182$ & $\$ 940,358$ & $-\$ 1,176$ & $\$ 937,772$ & $\$ 939,031$ & $-\$ 1,259$ & $\$ 882,128$ & $-0.1 \%$ & $-0.1 \%$ & $-6.6 \%$ \\
\hline & 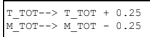 & & $\$ 941,595$ & $\$ 940,358$ & $\$ 1,237$ & $\$ 940,342$ & $\$ 939,031$ & $\$ 1,311$ & $\$ 882,128$ & $0.1 \%$ & $0.1 \%$ & $-5.6 \%$ \\
\hline & 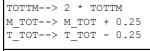 & TOTTM & $\$ 955,899$ & $\$ 940,358$ & $\$ 15,541$ & $\$ 953,507$ & $\$ 939,031$ & $\$ 14,476$ & $\$ 882,128$ & $1.6 \%$ & $1.5 \%$ & $7.4 \%$ \\
\hline & TNEI_t -0 & & $\$ 940,252$ & $\$ 940,358$ & $-\$ 106$ & $\$ 938,937$ & $\$ 939,031$ & $-\$ 94$ & $\$ 882,128$ & $0.0 \%$ & $0.0 \%$ & $12.8 \%$ \\
\hline & MaEEI_M -0 & MNEI_M & $\$ 941,585$ & $\$ 940,358$ & $\$ 1,227$ & $\$ 940,213$ & $\$ 939,031$ & $\$ 1,182$ & $\$ 882,128$ & $0.1 \%$ & $0.1 \%$ & $3.8 \%$ \\
\hline & 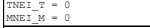 & MNEI_M & $\$ 941,479$ & $\$ 940,358$ & $\$ 1,121$ & $\$ 940,119$ & $\$ 939,031$ & $\$ 1,088$ & $\$ 882,128$ & $0.1 \%$ & $0.1 \%$ & $3.0 \%$ \\
\hline & 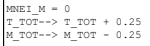 & MNEI_M & $\$ 942,822$ & $\$ 940,358$ & $\$ 2,464$ & $\$ 941,524$ & $\$ 939,031$ & $\$ 2,493$ & $\$ 882,128$ & $0.3 \%$ & $0.3 \%$ & $-1.2 \%$ \\
\hline \multirow{6}{*}{ MODEL 12} & IAR2 $-->2 *$ IAR2 & IAR2 & $\$ 959,456$ & $\$ 943,935$ & $\$ 15,521$ & $\$ 956,931$ & \begin{tabular}{|l|l|}
$\$ 942,443$ \\
\end{tabular} & $\$ 14,488$ & $\$ 882,128$ & $1.6 \%$ & $1.5 \%$ & $7.1 \%$ \\
\hline & TOOT->> 2 * TOT & TOT & $\$ 961,464$ & $\$ 943,935$ & $\$ 17,529$ & $\$ 959,125$ & $\$ 942,443$ & $\$ 16,682$ & $\$ 882,128$ & $1.9 \%$ & $1.8 \%$ & $5.1 \%$ \\
\hline & 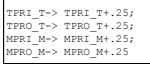 & MPRI_M & $\$ 944,007$ & $\$ 943,935$ & $\$ 72$ & $\$ 942,535$ & $\$ 942,443$ & $\$ 92$ & $\$ 882,128$ & $0.0 \%$ & $0.0 \%$ & $-21.7 \%$ \\
\hline & $\begin{array}{l}\text { TPRI_T-> TRRI_T+. } 25 ; \\
\text { TPRO_Ts }\end{array}$ & & $\$ 943,630$ & $\$ 943,935$ & $-\$ 305$ & $\$ 942,189$ & $\$ 942,443$ & $-\$ 254$ & $\$ 882,128$ & $0.0 \%$ & $0.0 \%$ & $20.1 \%$ \\
\hline & 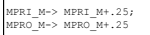 & MPRI_M & $\$ 944,313$ & $\$ 943,935$ & $\$ 378$ & $\$ 942,789$ & $\$ 942,443$ & $\$ 346$ & $\$ 882,128$ & $0.0 \%$ & $0.0 \%$ & $9.2 \%$ \\
\hline & 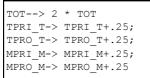 & TOT, MPRI_M & $\$ 961,563$ & $\$ 943,935$ & $\$ 17,628$ & $\$ 959,242$ & $\$ 942,443$ & $\$ 16,799$ & $\$ 882,128$ & $1.9 \%$ & $1.8 \%$ & $4.9 \%$ \\
\hline
\end{tabular}


TABLE 3 (cont.)

\begin{tabular}{|c|c|c|c|c|c|c|}
\hline LOG FILE & VARIABLE SUBSTITUTION & $\begin{array}{l}\text { SIGNIFICANT } \\
\text { VARIBLES } \\
\text { (B) }\end{array}$ & $\begin{array}{l}\text { ESTIMATED REPORTED TAX } \\
\text { REVENUE INCREASE } \\
\text { RESULTING FROM CHANGE } \\
\text { (Indirect Revenue Effect) } \\
\text { (C) }\end{array}$ & $\begin{array}{l}\text { ESTIMATED ASSESSED TAX } \\
\text { REVENUE INCREASE } \\
\text { RESULTING FROM CHANGE }\end{array}$ & $\begin{array}{c}\text { DIFFERENCE } \\
\text { (Direct Revenue Effect) }\end{array}$ & \begin{tabular}{|} 
INDIRECT \\
REVENUE \\
EFFECT / TOTAL \\
REVENUE \\
EFFECT \\
\\
C / D
\end{tabular} \\
\hline \multirow{8}{*}{ MODEL 9} & IAR2 $-->2$ * IAR2 & IAR2 & $\$ 18,500,000,000$ & $\$ 19,609,000,000$ & $\$ 1,109,000,000$ & $94.3 \%$ \\
\hline & $T-->2 * T$ & & $\$ 2,170,000,000$ & $\$ 2,921,000,000$ & $\$ 751,000,000$ & $74.3 \%$ \\
\hline & $M-->2 * M$ & $\mathrm{M}$ & $\$ 15,347,000,000$ & $\$ 15,571,000,000$ & $\$ 224,000,000$ & $98.6 \%$ \\
\hline & 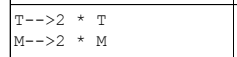 & M & $\$ 17,640,000,000$ & $\$ 18,605,000,000$ & $\$ 965,000,000$ & $94.8 \%$ \\
\hline & $\begin{array}{l}\text { TNEI_T }=0 \\
\text { MNEI_M }=0\end{array}$ & MNEI_M & $\$ 1,056,000,000$ & $\$ 1,091,000,000$ & $\$ 35,000,000$ & $96.8 \%$ \\
\hline & TNEI_T $=0$ & & $-\$ 128,000,000$ & $-\$ 138,000,000$ & $-\$ 10,000,000$ & $92.8 \%$ \\
\hline & MNEI_M $=0$ & MNEI_M & $\$ 1,184,000,000$ & $\$ 1,230,000,000$ & $\$ 46,000,000$ & $96.3 \%$ \\
\hline & 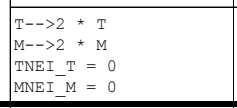 & M, MNEI_M & $\$ 18,696,000,000$ & $\$ 19,696,000,000$ & $\$ 1,000,000,000$ & $94.9 \%$ \\
\hline \multirow{5}{*}{ MODEL 10} & IAR2 --> $2 *$ IAR2 & IAR2 & $\$ 14,436,000,000$ & $\$ 15,457,000,000$ & $\$ 1,021,000,000$ & $93.4 \%$ \\
\hline & TОттM--> $2 *$ тоттM & TOTTM & $\$ 16,421,000,000$ & $\$ 17,402,000,000$ & $\$ 981,000,000$ & $94.4 \%$ \\
\hline & 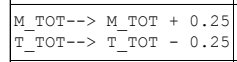 & & $-\$ 1,930,000,000$ & $-\$ 1,890,000,000$ & $\$ 40,000,000$ & $102.1 \%$ \\
\hline & \begin{tabular}{|l|l|} 
T_TOT-> T_TOT + & 0.25 \\
M_TOT--> M_TOT -0.25 \\
\end{tabular} & & $\$ 1,936,000,000$ & $\$ 1,903,000,000$ & $-\$ 33,000,000$ & $101.7 \%$ \\
\hline & \begin{tabular}{|l|} 
TOTTM--> $2 *$ TOTTM \\
M_TOT--> M_TOT + 0.25 \\
T_TOT--> T_TOT -0.25
\end{tabular} & TOTTM & $\$ 14,521,000,000$ & $\$ 15,542,000,000$ & $\$ 1,021,000,000$ & $93.4 \%$ \\
\hline \multirow{9}{*}{ MODEL 11} & IAR2 $-->2 *$ IAR2 & IAR2 & $\$ 17,571,000,000$ & $\$ 18,706,000,000$ & $\$ 1,135,000,000$ & $93.9 \%$ \\
\hline & TOттM--> 2 * тоттM & TOTTM & $\$ 15,698,000,000$ & $\$ 16,680,000,000$ & $\$ 982,000,000$ & $94.1 \%$ \\
\hline & \begin{tabular}{|l|l|} 
M_TOT--> M_TOT +0.25 \\
T_TOT--> T_TOT -0.25 \\
\end{tabular} & & $-\$ 1,259,000,000$ & $-\$ 1,176,000,000$ & $\$ 83,000,000$ & $107.1 \%$ \\
\hline & \begin{tabular}{|l|l|} 
T_TOT--> T_TOT +0.25 \\
M_TOT--> M_TOT -0.25 \\
\end{tabular} & & $\$ 1,311,000,000$ & $\$ 1,237,000,000$ & $-\$ 74,000,000$ & $106.0 \%$ \\
\hline & \begin{tabular}{|l|} 
TOTTM--> $2 *$ TOTTM \\
M_TOT--> M_TOT +0.25 \\
T_TOT--> T_TOT -0.25 \\
\end{tabular} & TOTTM & $\$ 14,476,000,000$ & $\$ 15,541,000,000$ & $\$ 1,065,000,000$ & $93.1 \%$ \\
\hline & TNEI_T $=0$ & & $-\$ 94,000,000$ & $-\$ 106,000,000$ & $-\$ 12,000,000$ & $88.7 \%$ \\
\hline & MNEI_M $=0$ & MNEI_M & $\$ 1,182,000,000$ & $\$ 1,227,000,000$ & $\$ 45,000,000$ & $96.3 \%$ \\
\hline & $\begin{array}{l}\text { TNEI_T }=0 \\
\text { MNEI_M }=0\end{array}$ & MNEI_M & $\$ 1,088,000,000$ & $\$ 1,121,000,000$ & $\$ 33,000,000$ & $97.1 \%$ \\
\hline & \begin{tabular}{l|} 
MNEI_M $=0$ \\
T_TOT--> T_TOT + +0.25 \\
M_TOT--> M_TOT -0.25
\end{tabular} & MNEI_M & $\$ 2,493,000,000$ & $\$ 2,464,000,000$ & $-\$ 29,000,000$ & $101.2 \%$ \\
\hline \multirow{6}{*}{ MODEL 12} & \begin{tabular}{|ll|l} 
IAR2 & $->$ & $*$ \\
\end{tabular} & IAR2 & $\$ 14,488,000,000$ & $\$ 15,521,000,000$ & $\$ 1,033,000,000$ & $93.3 \%$ \\
\hline & \begin{tabular}{|l|l|} 
TOT--> $2 *$ TOT \\
\end{tabular} & TOT & $\$ 16,682,000,000$ & $\$ 17,529,000,000$ & $\$ 847,000,000$ & $95.2 \%$ \\
\hline & 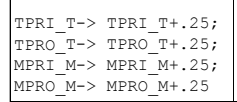 & MPRI_M & $\$ 92,000,000$ & $\$ 72,000,000$ & $-\$ 20,000,000$ & $127.8 \%$ \\
\hline & $\begin{array}{l}\text { TPRI_T-> TPRI_T+.25; } \\
\text { TPRO_T-> TPRO_T+.25 } \\
\end{array}$ & & $-\$ 254,000,000$ & $-\$ 305,000,000$ & $-\$ 51,000,000$ & $83.3 \%$ \\
\hline & $\begin{array}{l}\text { MPRI_M-> MPRIMM+. } 25 ; \\
\text { MPRO_M-> MPRO_M+.25 }\end{array}$ & MPRI_M & $\$ 346,000,000$ & $\$ 378,000,000$ & $\$ 32,000,000$ & $91.5 \%$ \\
\hline & $\begin{array}{l}\text { TOT--> } 2 \text { * TOT } \\
\text { TPRI_T-> TPRI_T+.25; } \\
\text { TPROTT-> TPROTT+.25; } \\
\text { MPRI_M-> MPRI_M+.25; } \\
\text { MPRO_M-> MPRO_M+.25 }\end{array}$ & TOT, MPRI_M & $\$ 16,799,000,000$ & $\$ 17,628,000,000$ & $\$ 829,000,000$ & $95.3 \%$ \\
\hline
\end{tabular}




\section{REFERENCES}

Ali, Mukhtar M., H. Wayne Cecil, and James A. Knoblett. "The Effects of Tax Rates and Enforcement Policies on Taxpayer Compliance: A Study of Self-Employed Taxpayers." American Economic Journal, Volume 29, No. 2, June 2001: 186-202.

Anderson and Hsiao, "Estimation of Dynamic Models with Error Components," Journal of the American Statistical Association, Vol. 76, September 1981, pp. 598-606.

Anderson and Hsiao, "Formulation and Estimation of Dynamic Models Using Panel Data," Journal of Econometrics, Vol. 18, 1982, pp. 47-82.

Andreoni, James, Brian Erard, Jonathan Feinstein. "Tax Compliance.” Journal of Economic Literature, Volume 36, No. 2, June 1998: 818-860.

Arellano, "A Note on the Anderson-Hsiao Estimator for Panel Data," Economic Letters, Vol. 31, 1989, pp. 337-341.

Arellano and Bond, "Some Tests of Specification for Panel Data: Monte Carlo Evidence and its Application to Employment Equations," Review of Economic Studies, Vol. 58, 1991, pp. 277297.

Beron, Kurt, Helen Tauchen and Ann Witte. "Tax Compliance: An Investigation Using Individual Tax Compliance Measurement Program (TCMP) Data." Journal of Quantitative Criminology, Volume 9, No.2 1993: 177-202.

Dubin, Jeffrey A. and Louis L. Wilde. "An Empirical Analysis of Federal Income Tax Auditing and Compliance." National Tax Journal, Volume 41, 1988: 61-74.

Dubin, Jeffrey A., Michael A. Graetz, and Louis L. Wilde. "The Changing Face of Tax Enforcement, 1978-1988." Tax Layer, Volume 43, No. 4, 1990: 893-914. 
Dubin, Jeffrey A., Michael J. Graetz, Michael A. Udell, and Louis L. Wilde. "The Demand for Tax Return Preparation Services.” The Review of Economics and Statistics, Volume 74, No. 1, February 1992: 75-82.

Dubin, Jeffrey A., Michael J. Graetz, and Louis L. Wilde. "The Effect of Audit Rates on the Federal Individual Income Tax, 1977-1986," National Tax Journal, Volume 43, 1990: 395-409.

Dubin, Jeffrey A., Michael J. Graetz, and Louis L. Wilde. "The Report of the United States to the International Fiscal Association on the Administrative and Compliance Cost of Taxation," Cahiers of the International Fiscal Association, 43 Congress, Kluwer, The Netherlands, 1989: $310-47$.

Dubin, Jeffrey A., Michael J. Graetz, and Louis L. Wilde. "Are We a Nation of Tax Cheaters? New Econometric Evidence on Tax Compliance," American Economic Review, Papers and Proceedings 77, 1987: 240-45.

Durlauf, S. and H. Peyton Young, Social Dynamics, Cambridge: The MIT Press, 2001.

Giles, David E. A. and Patrick J. Caragata. "The Learning Path of the Hidden Economy: the Tax Burden and Tax Evasion in New Zealand." Applied Economics, Volume 33, 2001: 1857-1867.

Kamdar, Nipoli. "Information Reporting and Tax Compliance: An Investigation Using Individual TCMP Data.” Atlantic Economic Journal, Volume 23, No. 4, December 1995: 278292.

Manski, C. 1993. "Identification of Endogenous Social Effects: The Reflection Problem." Review of Economic Studies, Vol. 60, pp. 531-542.

Manski, C. 1995. Identification Problems in the Social Sciences, Cambridge: Harvard University Press. 
Mete, Mihriye. "Bureaucratic Behavior in Strategic Environments: Politicians, Taxpayers, and the IRS.” The Journal of Politics, Volume 64, No. 2, May 2002: 384-407.

Plumley, Alan H. "The Determinants of Individual Income Tax Compliance: Estimating the Impacts of Tax Policy, Enforcement, and IRS Responsiveness.” Internal Revenue Service, Publication 1916 (Rev. 11-96), 1996.

Roth, J., J. Scholz and A. Witte. "Taxpayer Compliance: An Agenda for Research.” A National Research Council Report. Philadelphia: University of Pennsylvania Press, 1989.

Scholz J. “Trusting Government: Fear, Duty and Trust in Tax Compliance.” Trust and Governance. New York: Russell Sage Foundation, 1998.

Scholz, J. and M. Lubell. "Trust and Taxpaying: Testing the Heuristic Approach to Collective Action.” American Journal of Political Science. Volume 42, 1998: 398-417.

Scholz, J. and M. Lubell. “Adaptive Political Attitudes: Duty, Trust, and Fear as Monitors of Tax Policy." American Journal of Political Science. Volume 42, 1998: 903-920.

Slemrod Joel and Shlomo Yitzhaki. "Tax Avoidance, Evasion, and Administration.” Handbook of Public Economics, Volume 3, 2002: 1425-1470.

Webster, William H. Review of the Internal Revenue Service's Criminal Investigation Division. April 1999.

Witte, Ann D. and Diane F. Woodbury, "The Effect of Tax Laws and Tax Administration on Tax Compliance: The Case of the U.S. Individual Income Tax." National Tax Journal, Volume 38, 1985: 1-14. 